\title{
Recent Characteristics of the Second Home Phenomenon in the Croatian Littoral
}

\author{
Vuk Tvrtko Opačić
}

The study analyses the characteristics of developmental dynamics and spatial distribution of the second home phenomenon in the Croatian littoral, the leading receiving second home area in the country, after the Second World War, with particular emphasis on the recent period (after the Homeland War and Croatian liberation). The period of the conversion and adaptation of the existing and abandoned housing stock into recreational second homes (mostly in 1960s and 1970s) and the period of the construction of the purpose-built dwellings for vacation and recreation, i.e. family weekend-houses (in 1970s and 1980s), was followed by the period of a more intensive construction of multi-apartment recreational buildings (from mid 1990s until the present time). The second home phenomenon first spread in the area of the Northern Croatian Littoral. Then, between 1980 and 1990, it made significant inroads also into Dalmatia. After the Homeland War and in the last ten years, it again became more prominent in the Kvarner and Istria. The geographical distribution of dwellings for vacation and recreation in 2001, covering the period between the two censuses of 1991 and 2001, reveals the persistence of earlier trends towards greater concentration of second homes in the leading tourist regions along the Croatian littoral, but also the increased dispersion into the regions which do not have as high value for tourism but are suitable for accommodating second home dwellings.

Key words: second home phenomenon, second home, receiving second home area, Croatian littoral

\section{Suvremena obilježja vikendaštva u hrvatskom priobalju}

U radu su analizirana obilježja razvojne dinamike i prostornog rasporeda vikendaštva nakon Drugoga svjetskog rata u priobalnom dijelu Hrvatske, vodećem receptivnom vikendaškom području u državi, s posebnim naglaskom na suvremeno razdoblje (nakon Domovinskog rata $\mathrm{i}$ hrvatskog osamostaljenja). U njemu je nakon faze prenamjene $\mathrm{i}$ adaptacije postojećega i ispražnjenoga stambenog fonda u vikendice (najviše 1960-ih i 1970-ih godina) i faze izgradnje namjenskih objekata za odmor i rekreaciju, tj. obiteljskih vikendica (1970-ih i 1980-ih) nastupila faza pojačane izgradnje višestambenih apartmanskih kompleksa (od sredine 1990-ih do danas). Vikendaštvo je u priobalju najprije zahvatilo prostor Sjevernoga hrvatskog primorja, potom je između 1980. i 1990. znatno ojačalo i u Dalmaciji te se nakon Domovinskog rata u posljednjih desetak godina ponovno jače koncentriralo na Kvarneru i u Istri. Prostorni raspored stanova za odmor i rekreaciju 2001. otkriva da su se i u posljednjemu međupopisnom razdoblju (1991.-2001.) zadržale tendencije koncentracije sekundarnoga stanovanja u vodećim obalnim turističkim područjima, ali i sve izraženija disperzija u turistički manje vrednovana područja pogodna za vikendašku valorizaciju. priobalje

Ključne riječi: vikendaštvo, vikendica, receptivno vikendaško područje, hrvatsko 


\section{INTRODUCTION}

As in other parts of the world characterised by the highly developed second home phenomenon, the number of dwellings for vacation and recreation in Croatia underwent a rather steep increase in the last forty years. Due to the exceptional value of second homes for personal recreation and as premises which can be rented out, the majority of second homes in Croatia are traditionally concentrated in its coastal and island area, which is the most developed tourist region of Croatia. For this reason the Croatian littoral can be considered the leading receiving second home area in the country.

In addition to the specific socio-economic relationships which were in place in the socialist Yugoslavia, the following factors contributed to the almost exponential growth of temporary second homes in the decades following the end of the Second World War: the overall increase in the standard of living, the growth of the number of personal vehicles, better traffic communications, the excess of free time, the surplus of available amenities (secondary living becomes a wider social phenomenon), the higher stress level of urban life, the change of attitude towards nature and the search for identity and family roots.

Similarly as in other countries with a long tradition of second home ownership (European Mediterranean countries, Scandinavian countries, Alpine countries, USA, Canada, Australia, New Zealand, etc.), the first wave of widespread second home acquisition in Croatian receiving second home areas also took place after the Second World War (in 1950s, 1960s and 1970s). Since the country was a socialist state, the second home phenomenon was exclusively domestic in character. The "new wave" of the second home phenomenon, which in other parts of the world commenced in early 1990s and in Croatia in the aftermath of the Homeland War and the peaceful restructuring of the country (in the late 1990s), was domestic but increasingly international in character. It is precisely this internationalisation, clearly manifested in Croatia as well, which points to the increased globalisation in the nature of secondary dwelling.

The main factors contributing to the growth and internationalisation of the secondary home phenomenon in the world and in Croatia during the "new wave" were: marked increase in traffic (particularly road and air traffic), further investments in the technology and services of the receiving second home areas, further improvements in infrastructure (water and electricity supply), increase in the number of agents involved in tourism (tour operators, travel agencies, timesharing companies) as well as the increased number of real estate agencies who helped channel real estate offers to target areas (Gallent, TewdwrJones, 2000; Müller, 2002; Müller, 2004).

Other factors contributing to the strengthening of the international aspect of the second home phenomenon were: improved telecommunications, increased flexibility of working hours and the place of work, i.e. work at a distance (teleworking), and the internationalisation of the real estate market paralleling the growth of the European Union (Chaplin 1999; Müller, 1999). An important factor in the recent growth of the second home phenomenon is also the increased international mobility of retired population which often results in their spending half a year or the whole year in second dwellings (Williams et al. 1997; Warnes, King, Patterson, 1998; Rodríguez, 2001; Gustafson, 2002; Truly, 2002; Müller, Hall, 2004; Williams et al., 2004). 
In addition to its sheer growth in volume, in the last one hundred years the second home phenomenon has experienced significant changes in its character both in the world and in Croatia. In the past, until the Second World War, second homes were the privilege of the rich(est). After the Second World War it became a wider social phenomenon. In the recent times, paralleling the sudden boom in tourism and the needs generated by more free time, due to the increased demand and the dramatic rise of real estate prices, the second home phenomenon has again increasingly become an elitist phenomenon reserved primarily for the population of the higher economic standing (Halseth, 2004; Müller, Hall, 2004).

The same dramatic change has reflected also on the dwellings for vacation and recreation which today, after the period dominated by luxurious villas, and subsequently by family weekend houses, in the Croatian littoral ever more frequently appear as multiapartment buildings intended for the recreation of their owners, but also for making profit through renting.

\section{AIM, METHODOLOGY AND SPATIAL FRAMEWORK OF THE STUDY}

The emergence and development of the second home phenomenon has indubitably had both direct and indirect effect on the transformation of the Croatian littoral. Before a thorough research of the role which the secondary (recreational) dwellings play in the local communities of the receiving second home areas of the Croatian littoral, and the subsequent elaboration of relevant guidelines for their future development, it is necessary to investigate the characteristics of the developmental dynamics and spatial distribution of this complex phenomenon in the "core region" of the second home phenomenon in Croatia, and identify its foci. The latter will be the main aim of this study.

The study is based on the analysis of the Croatian and international theoretical and empirical scientific literature dealing with geography and related disciplines, as well as the interpretation of available national statistics. The Croatian national Censuses of Population, Households and Dwellings from 1971, 1981, 1991 and 2001 included dwellings for vacation and recreation as a separate category within the overall housing fund.

The spatial framework of the study is defined by the area covering the Croatian coastal region, or more precisely Croatian littoral. This term includes the area of Croatian coast, islands and their immediate hinterland which together form an inseparable functional unit connected by daily interactions. Respecting standard combined geographical criteria for defining spatial units, strict division of geographical areas have taken into account the administratively-territorial structure, functional directionality - that is, established communicational framework - as well as basic geographical characteristics of the region.

Therefore, for the purposes of this study the spatial framework of the Croatian littoral includes all towns and municipalities which have access to the sea and those units of local self-government which do not, but whose administrative seats are less than $10 \mathrm{~km}$ of road distance away from the nearest coastal settlement ${ }^{1}$. In this way we have defined 134 units of local self-government (42 towns and 92 municipalities) covering in total $11241 \mathrm{~km}^{2}$, 
which represents $45.49 \%$ of the total territory of Croatian counties which have access to sea, or $19.89 \%$ of the overall territory of Croatia $^{2}$.

In order to provide a full picture, relevant quantitative information relative to the littoral region of Croatia are presented and analysed on several levels of vertical and horizontal geographical differentiation. They cover the following geographical categories: the islands area ${ }^{3}$ by larger groups of islands and their location with regard to the mainland, the comparison of the islands region with the coastal and continental areas of the counties with access to $\mathrm{sea}^{4}$, and the comparison of the counties with access to sea and continental counties as well as Croatia as a whole.

\section{THE DEVELOPMENT OF THE SECOND HOME PHENOMENON IN THE CROATIAN LITTORAL}

One of the contributing factors of the "holiday orientation" of the socialist Yugoslavia was certainly the rise of (international) tourism in the Croatian littoral from the early $1960 \mathrm{~s}$ onwards. As a result, the Croatian littoral increasingly acquired the reputation as the most attractive region for vacation and recreation. Parallel to the development of tourism came the growth of temporary recreational dwelling, promoted to a large degree also by the state-orchestrated advertising of the Croatian littoral as the region suitable for tourism, but also underpinned by a more liberal attitude towards private property of (secondary) real estate. This was accompanied by the relative increase in the standard of living, predominantly among urban population (for example through the increased number of private vehicles), which, in conjunction with the standardisation of working hours and the ever increasing pressure of urban way of life, contributed to the increase in the tourism demand and second homes (Duda, 2005).

The second home phenomenon in the Croatian littoral, as in the rest of the world, after the Second World War and henceforth became increasingly significant for the development of that region. In addition to the overall increase in the standard of living, the growth of the second home phenomenon along the whole length of the Croatian littoral was supported by improved road connections between the littoral and the hinterland, coast and islands, as well as the integration of the whole Croatian coast due to the construction and modernisation of important communication routes (Zagreb - Rijeka, Zagreb - Plitvice Lakes National Park - Zadar, then Split, the Adriatic carriage-way, etc.). Some of the earliest second dwellings were purpose-built one at a time, but others came into being through the adaptation and conversion of the residential and economic objects whose earlier occupants had emigrated or died ${ }^{5}$.

The main incentive for the development of the second home phenomenon in the socialist system, perhaps even more so than in the capitalist system, was saving, that is, the hoarding of capital by individuals (Poljanec-Borić, 1991). In the conditions characterised by high inflation rate and the non-existence of the market economy, and on the other hand by housing loans on favourable terms (Mikačić, 1994; Mikačić, 2007) which could also be approved for the purchase of second dwellings, the value of the surplus of capital was 
best protected through investing in real estate, which was by and large "an equivalent of entrepreneurial behaviour" (Gosar, 1989; Poljanec-Borić, 1991).

An additional incentive for the emergence of the first significant wave of second homes in Croatia after the Second World War in 1960s and 1970s was the low price of land along the Adriatic coast. The concept of paleo-industrial urbanisation, or littoralisation, facilitated the emergence of the notion of the inexhaustibility of space. It fed into the idea of the development of mass tourism as well as the development of secondary recreational dwelling in the Croatian littoral. As a result, in 1970s and 1980s the hitherto relatively undeveloped second home phenomenon transformed into one of the most distinguished usurpers of attractive land in many settlements of the Croatian littoral (Pepeonik, 1983). In the period of enthusiastic growth of second homes in 1960s and 1970s the majority of second homes were built without proper permits, but with the tacit approval of local authorities. Their legalisation followed later (Alfier, 1987; Rogić, 2006).

However, from mid 1980s onwards the vigorous construction of detached second houses experienced slight decline. One of the reasons was that suitable and available land was becoming scarce, particularly in the immediate vicinity of the sea, and the other was stricter control of urban planning. The price of land experienced considerable rise, which consequently caused building of new houses to slow down (Klarić, 1989).

In the period of socialist Yugoslavia the dominant type of a dwelling for vacation and recreation was a purpose-built family house designated for vacation and recreation of its owners/users. In contrast to luxurious villas surrounded by groomed vegetation, which dominated the pioneering phase of the development of the second home phenomenon in the Croatian littoral (before the Second World War), the second homes from the socialist period were not as large and luxurious but relatively smaller and more modest buildings intended for a wider circle of owners (Pepeonik, 1983). In contrast to villas, the number of second homes was incomparably higher, which points to the fact that secondary recreational dwelling in the period of socialist Yugoslavia became a mass phenomenon.

Secondary dwellings of the earlier developmental phase of the second home phenomenon in the socialist Yugoslavia emerged predominantly through the conversion and adaptation of the existing abandoned buildings, both residential and commercial (e.g. vineyard huts, barns, shepherds' dwellings, fisheries), and later through the individual building of purpose-built second homes. When, for example, the stock of all available empty and abandoned houses and commercial buildings, suitable conversion into second homes, in desirable coastal receiving areas became depleted and the "stock exhausted," relatively liberal legislation related to urban planning allowed mass building of purposebuilt secondary dwellings. This was accompanied by a process whereby the conversion and adaptation of the existing old buildings "moved" to less suitable locations of the hinterland, first nearer to the coast and then further away in the hinterland, and to islands closer to the mainland, then to islands less attractive and further away from the mainland (Blažević, 1984).

The primary core areas of secondary dwellings in the Croatian littoral were the leading tourist resorts with a long history of tourism which were also geographically closest to the emissive second home regions, primarily in the areas of Kvarner and 
Istria (Pepeonik, 1977), with documented parallel interest in tourism and second homes (e.g. Crikvenica, Novi Vinodolski, Opatija, Rovinj, Mali Lošinj, Baška, Malinska, Rab). Apart from the trend to cluster around the earlier established tourist resorts, the second home phenomenon in the socialist Yugoslavia shows evidence of spatial dispersion towards smaller settlements which, in terms of tourism, were still "undiscovered" or less valued. These settlements were located in the hinterland near the coast (e.g. Istria, Vinodol), but also in the immediate hinterland of larger islands (e.g. Krk). This points to the fact that secondary dwelling in conjunction with tourism may display a double character. The second home phenomenon may be the cause of tourism development (its initial phase), that is, may precede the tourism valorisation of a location or area, but it may also be the result of tourism development.

While the receiving second home areas of Kvarner and Istria experienced most intensive growth in second homes in earlier periods due to the close proximity to the most important emissive second home regions, in the period between 1981 and 1991 the relative increase in dwellings for vacation and recreation was higher in Dalmatia. This confirms the further dispersion of second dwellings into the Croatian littoral.

A particular form of a secondary recreational dwelling emerged in the second half of 1980s in the Croatian littoral: purpose-built multi-apartment buildings which appear as self-standing objects or as parts of separate, purpose-built apartment villages ${ }^{6}$. The emergence of multi-apartment buildings, which characterises the development of secondary dwellings in the Croatian littoral after the independence of Croatia and the end of the Homeland War (from 1995 until today), introduces collective dwelling into the second home phenomenon in the Croatian littoral.

The Homeland War (1991 - 1995), imposed on Croatia, marked the dissolution of the socialist Yugoslavia and the establishment of Croatia as an independent state. In addition to the changed political reality, Croatia also experienced the change of political system, the transition from socialism and centrally-planned economy to capitalism and free-market economy. Suffering direct and indirect consequences of the war, Croatian economic development was also slowed down by difficulties related to economic and political transition which, because of the war and the post-war circumstances, lasted longer than in other post-socialist countries. The first decade of $21^{\text {st }}$ century witnessed Croatian political and economic advance towards to the European Union and the European market, the rise in foreign investment and gradual recovery of the country's economy.

Unfavourable socio-economic circumstances, which characterised early 1990s, exerted extremely negative consequences on the standard of living and the buying power of Croatian population in this period and to the end of the decade. Nevertheless, with the end of military conflict in early 2000s, secondary recreational dwelling occupied ever more prominent place on the Croatian real estate market, primarily in the Croatian littoral, and domestic buyers were soon joined by increased foreign demand ${ }^{7}$.

Despite radical changes of political and economic circumstances and "the rules of the game", in the aftermath of achieved political independence the second home phenomenon retained numerous traits of the previous era. The main characteristics witnessing the continuity with the previous period can be identified in the following: a) continued 
inconsiderate attitude towards space as an inexhaustible good despite declared respect for official guidelines for geographic planning; b) an ever more intensive construction of buildings designed for renting; and c) increased economic unsustainability of local communities.

The creation of the real estate market in Croatia resulted in the sudden rise in the price of building sites and dwellings for vacation and recreation in the littoral areas of Croatia. The increased interest in tourism caused violent scuffle for more land to build on, often blatantly disregarding urban planning legislation. Further, in many cases the pressure was exerted on relevant authorities to hastily adopt a framework for urban planning based exclusively on, and legitimising, market laws. The turbulent 1990s also meant a step backwards in relation to spatial planning, so that the hitherto established practice of chaotic building and its subsequent legalisation often continued in the period after the Homeland War.

Commercial second home ownership, that is renting dwellings for vacation and recreation to tourists, has its roots in the early 1980s when a phenomenon colloquially called "Zimmer frei" spread along the Croatian littoral. This form of entrepreneurship became not just a supplementary source of income but a necessity in many households. This happened because a considerable number of people in Croatia, as elsewhere, lost their jobs during transition, because of which a proportion of households in the receiving tourist-second home areas embraced the renting of rooms, apartments and whole houses as one, or the only solution to unemployment, that is, as the main source of income. In addition, owners of second homes also more and more often engaged in renting their own second homes and apartments as a supplementary source of income (Opačić, 2008).

Since many small and weak municipalities and towns of the Croatian littoral, which is a direct result of the highly fragmented administrative-territorial division of Croatia ${ }^{8}$, did not have any other opportunities for development, they recognised land as their only resource offering any chance for their development, particularly that strip of land along the coast which has been in highest demand since the establishment of the real estate market. This resource has indeed provided the greatest single source of income for many local budgets. The already mentioned practice of conversion of agricultural and forest land into building sites is also characteristic of "stronger" and larger towns and municipalities in the Croatian littoral. In this way units of local self-government join the process of apartmentising and "concretesation" of the Croatian littoral.

Further to these three socio-economic trends whose start can be traced back to the period of the previous developmental phase and its continuity registered in the intervening period, two new processes emerged in Croatia after 1990 which left an indelible mark on the contemporary character of secondary dwelling. One is a) the strengthening of the legal and social position of the institution of private property, and the other, closely related, is b) the emergence of private entrepreneurship (Rogić, 2006).

The main consequence of the revival of private property ${ }^{9}$, important for the development of second homes, is the establishment of the real estate market, which includes dwellings for vacation and recreation as a significant element, particularly in the Croatian littoral. The strengthening of notion of private property in Croatia was accompanied by the gradual development of private enterprise. The building lobby of private enterprises, 
within the context of the second home phenomenon, achieved a position of great power among other reasons because the existence of the actual real estate market effected the sudden price growth, particularly in most attractive receiving second home areas of the Croatian littoral. In contrast to the socialist period, the large number of potential owners are not financially able to build individually, and consequently many of the opt for collective secondary dwellings, that is the purchase of apartments in purpose-built multi-apartment buildings. Because of the great demand for apartments, the building lobby has, within the context of the second home phenomenon, achieved a position of great power, so that apartments, as premises designed for vacation and recreation which the future owners do not build individually but purchase from the investor, have turned into a "brand" of contemporary second home phenomenon in the Croatian littoral. The construction of multi-apartment buildings is actually a reflection of new socio-economic circumstances, i.e. the outcome of the interaction among the interests of owners of land, building investors and local authorities.

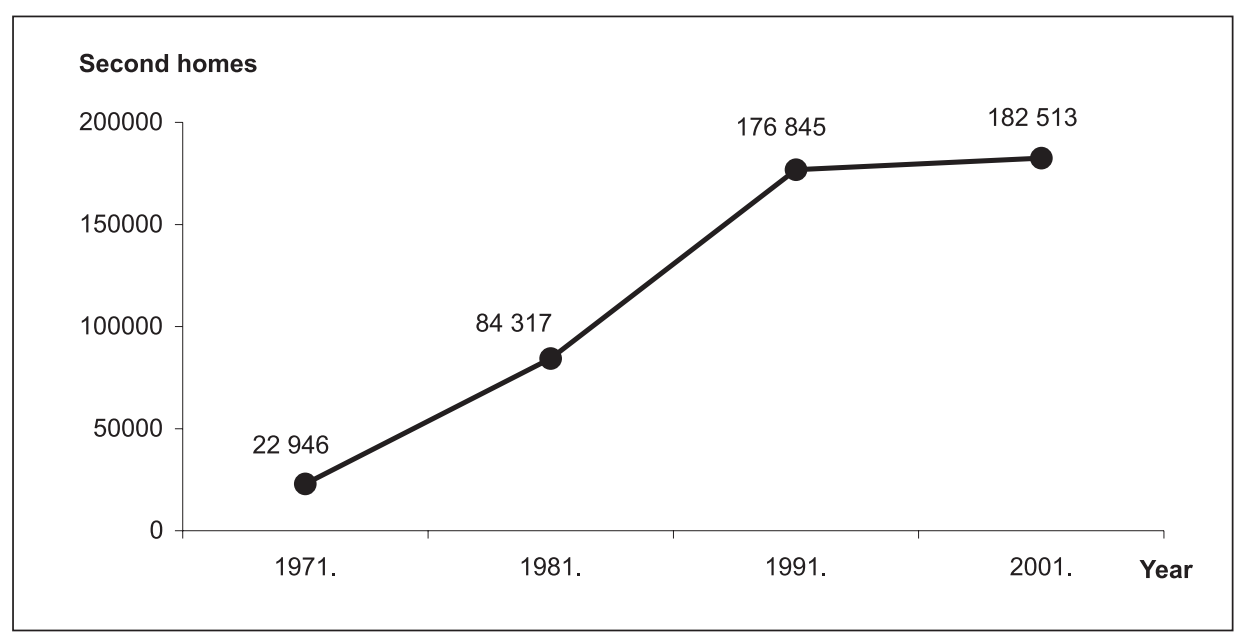

Fig. 1 The number of dwellings for vacation and recreation in Croatia from 1971 to 2001

Sl. 1. Kretanje broja stanova za odmor i rekreaciju u Hrvatskoj od 1971. do 2001.

Sources: Census of Population and Dwellings 1971, Dwellings for vacation and recreation. Statistics by settlements and municipalities, Book 6, Federal Bureau of Statistics, Beograd, 1973.

Census of Population, Households and Dwellings $31^{\text {st }}$ March 1981, Households and dwellings. Statistics for settlements by municipalities, Dwellings and area by usage and other inhabited rooms and persons, Republic Bureau of Statistics, Zagreb, 1982.

Census of Population, Households, Dwellings and Farms 31 $1^{\text {st }}$ March 1991, Dwellings for vacation and recreation by settlements, Documentation 929, Central Bureau of Statistics of the Republic of Croatia, Zagreb, 1996.

Census of Population, Households and Dwellings $31^{\text {st }}$ March 2001, Dwellings according to the manner of use by towns/municipalities, Second edition, Central Bureau of Statistics of the Republic of Croatia, Zagreb, 2003.

http://www.dzs.hr/Popis\%202001/popis20001. htm

Thus, due to the establishment of the real estate market and the inauguration of the "apartment collectives" as its dominant morphological expression, the second home 
phenomenon in the Croatian littoral in the independent Croatia after 1990 has developed characteristics of "vacation and recreation industry". Further factors which define it as an "industry" are: its increasingly international character, a growing proportion of (foreign) retired persons within the body of population related to the second home phenomenon in the Croatian littoral, and the fact that more and more people purchase second homes for vacation and recreation as an investment. In the socialist period the prevailing rationale for purchasing dwellings for vacation and recreation was the recreation of the owner, their family and friends, while renting and the real estate speculation as rationale for purchasing dwellings for vacation and recreation became evident in the Croatian littoral only about ten years ago (in the late 1990s).

After several decades of manifest growth of the number of dwellings for vacation and recreation, in the period from 1991 and 2001 their number in Croatia increased by only 5668, which is only $3.21 \%$ more than in the pre-War 1991 (Fig. 1).

Such radical slowing of the total increase in the number of dwellings for vacation and recreation between the last two censuses in Croatia is a result of several factors. The most important are: direct and indirect consequences of the War, conversion of a proportion of dwellings for vacation and recreation into permanently occupied dwellings and the registration of dwellings which are actually used for vacation and recreation as permanently occupied dwellings, temporarily uninhabited dwellings and dwellings used exclusively for commercial purposes.

\section{THE DEVELOPMENTAL DYNAMICS OF THE SECOND HOME PHENOMENON IN THE CROATIAN LITTORAL IN THE PERIOD $1991-2001$}

Out of 182513 dwellings for vacation and recreation, the total for the whole of Croatia in 2001, the coastal and insular parts of Croatia had 107741 (59.03\% of all secondary dwellings in Croatia), which, contrary to earlier trends, testifies to a slight growth in the proportional share of the number of second homes in the Croatian littoral (In 1991 their share in the Croatian littoral was 54.39\%, in $198158.93 \%$, and in 1971 even 81.57\%). It is evident that in the period between the two consensuses of 1991 and 2001 the second home phenomenon in Croatia, despite stagnation (according to official figures), and because of a relatively more intensive building of multi-apartment recreational buildings, manifested a more pronounced trend towards the concentration in the territory of its initial core - the Croatian littoral.

The Croatian littoral, which has thus retained the function of the leading receiving second home area in the country, between 1991 and 2001 recorded a significantly higher relative growth in the number of dwellings for vacation and recreation $(12.02 \%)$ than Croatia as a whole (3.21\%). Nevertheless, in contrast with previous inter-census periods when the number of second homes in almost all towns/municipalities of the Croatian littoral constantly increased, between 1991 and 2001 as many as 49 among 132 units of local self-government of the Croatian littoral (37.12\%) recorded the decrease in the number of dwellings for vacation and recreation and 83 recorded increase $(62.88 \%)$. The index for the 
change of the number of dwellings for vacation and recreation ${ }^{10}$ in towns/municipalities of the Croatian littoral ranged from 566.67 (Kanfanar) and 23.63 (Ploče), and the average index was 112.02 (Fig. 2).

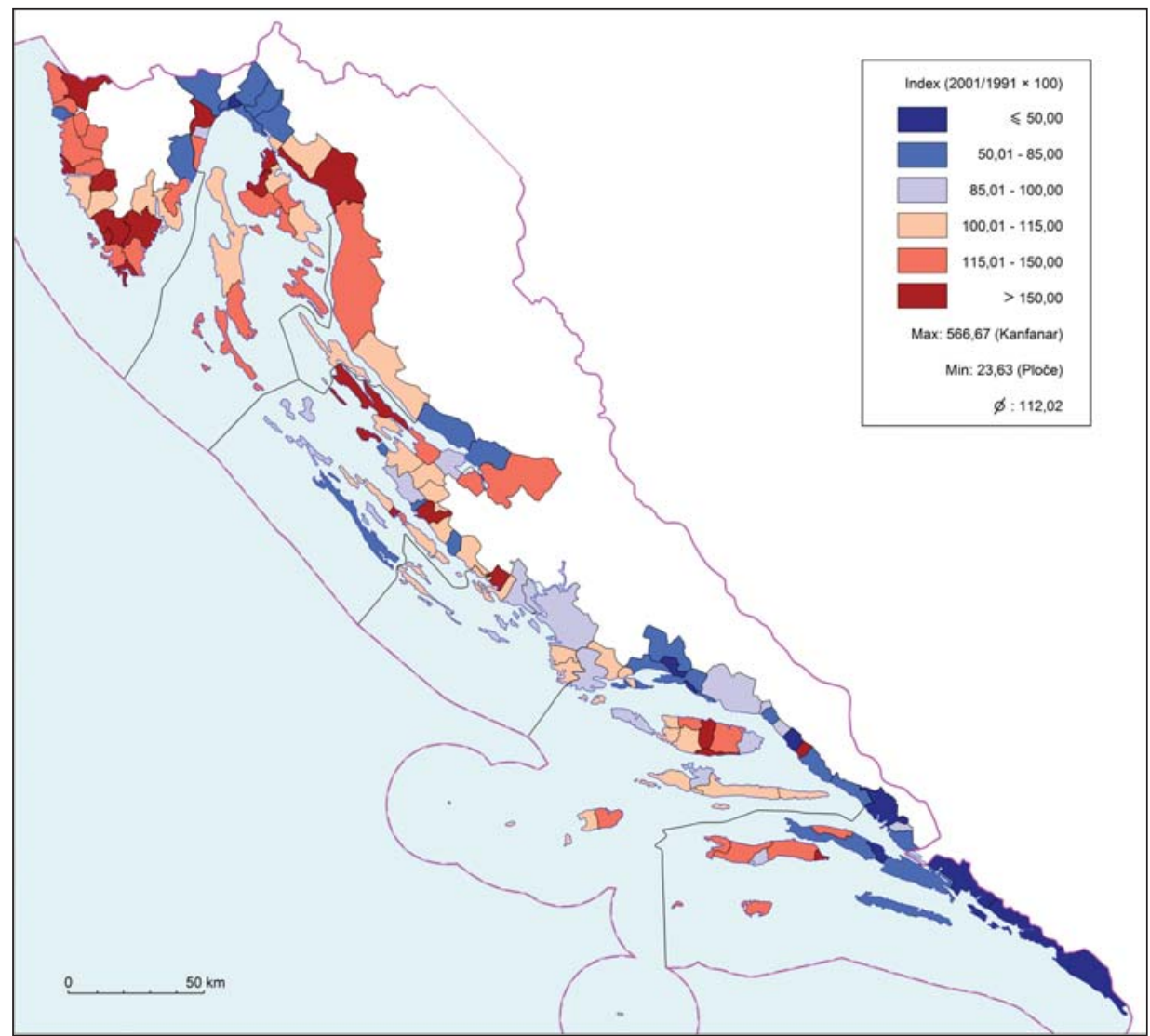

Fig. 2 The change in the number of dwellings for vacation and recreation in towns and municipalities of the Croatian littoral from 1991 to 2001

Sl. 2. Promjena broja stanova za odmor i rekreaciju u gradovima i općinama priobalnoga dijela Hrvatske od 1991. do 2001.

Sources: Census of Population, Households, Dwellings and Farms $31^{\text {st }}$ March 1991, Dwellings for vacation and recreation by settlements, Documentation 929, Central Bureau of Statistics of the Republic of Croatia, Zagreb, 1996.

Census of Population, Households and Dwellings $31^{\text {st }}$ March 2001, Dwellings according to the manner of use by towns/municipalities, Second edition, Central Bureau of Statistics of the Republic of Croatia, Zagreb, 2003.

http://www.dzs.hr/Popis\%202001/popis20001. htm

The index for the change in the number of second homes in towns/municipalities of the Croatian littoral from 1991 to 2001 reveals that the second home phenomenon continued to grow, albeit at a somewhat slower rate, in the majority of units of local self-government in the Northern Croatian Littoral, while in the towns and municipalities 
of its Southern part for the most part showed numerical decline. The main reason lies in the fact that the territory of the Northern Croatian Littoral, in contrast to the Southern Croatian Littoral, remained outside the area caught up in military operations during the Homeland War, so that the second home phenomenon developed in a more spontaneous manner and less dependant on direct and indirect consequences of the War than was the case with the Southern Croatian Littoral.

In the Istria and Primorje-Gorski kotar counties there are 12 out of 21 units of local self-government which from 1991 and 2001 recorded an one and a half times higher growth of second homes (Kanfanar - index for the change in the number of second homes from 1991 to 2001 - 566.67, Buje - 270.00, Malinska-Dubašnica - 189.62, Marčana - 182.29, Vodnjan - 175.10, Medulin - 163.19, Omišalj-161.63, Novi Vinodolski-160.34, Opatija -155.17, Crikvenica-154.52, Fažana-153.60, Vrsar-152.66). The towns/municipalities with a highest growth rate of dwellings for vacation and recreation in the region of Istria and Kvarner can be divided in this way: a) those which had previously emerged as important receiving second home areas (e.g. Malinska-Dubašnica, Novi Vinodolski, Crikvenica); and b) those which in 1991 had a relatively small number of dwellings for vacation and recreation and which due to the "law of small numbers" and according to the relevant index experienced a pronounced second home "boom" (e.g. Kanfanar, Buje, Fažana).

In contrast to previous inter-census periods, in the period from 1991 to 2001 there is hardly any difference in the dynamics of growth rate of dwellings for vacation and recreation between the coastal and continental parts of Istria. This is so even though Istria is farthest from the zone of military operations in the Homeland War and despite the introduction of Croatian legislation which allowed foreign nationals to purchase real estate in Croatia due to which Istria experienced the blossoming of secondary dwelling. The traditionally "strong" receiving second home areas of the Kvarner islands have retained this epithet in the last inter-census period as they have maintained, particularly on the island of Krk, a steady growth rate of second dwellings until today. The same applies to the middle part of the Croatian littoral which is closest to the strong emissive second home areas and which includes the Crikvenica-Vinodol and the Velebit coast (the Town of Senj - index for the change of the number in second homes from 1991 to 2001 - 142.78) with the island of Pag (the Town of Pag - 162.78).

The majority of units of local self-government in the Northern Croatian Littoral with registered decrease in the number of second homes lies in the territory of the Rijeka urban region (i.e. Bakar - index for the change in the number of second dwellings from 1991 to 2001 - 78.18, Čavle - 64.52, Kastav - 64.10, Matulji - 61.25, Jelenje - 52.94, Rijeka -51.98, Viškovo-30.19). Due to the proximity of the macro-regional centre with the strong job market, many second home owners have "re-registered" their objects into dwellings for permanent residency in an attempt to make some financial profit as well.

The coastal part of the Zadar and Šibenik-Knin counties suffered immense devastation due to the direct and indirect consequences of the Homeland War which has certainly reflected on the second home phenomenon in the area. However, the stagnation which is experienced by the second home market is not only due to the consequences of the Homeland War, but can be explained by the growing practice of registering dwellings for vacation and recreation as permanently occupied dwellings, particularly in the wider areas of larger 
cities of Zadar and Šibenik. Consequently, according to the most recent statistics, there are towns/municipalities in the territory of Northern Dalmatia with the index for the change in the number of second homes from 1991 to 2001 which is among highest in the whole Croatian littoral (e.g. Kali - 193.65, Vir - 161.87, Sukošan - 154.55, Pirovac - 150.25). However, and following no discernable spatial regularity, there are other units of local self-government in the same area with very marked decrease in the number of dwellings for vacation and recreation in the period from 1991 to 2001 (e.g. Starigrad - 84.86, Privlaka - 83.20, Jasenice - 82.51, Sali - 82.21, Bibinje - 80.75, Biograd na Moru - 74.93).

The coastal part of the Split-Dalmatia county, i.e. Middle Dalmatia, registered, at least "on paper", the decrease in the number of second homes in the last inter-census period. Even though "field situation" suggests just the opposite conclusion, the census statistics indicate that the steepest decrease in the number of dwellings for rest and recreation occurred in the Split urban region (the territory between Trogir and Omiš; e.g. Okrug -the index for the change in the number of second dwellings from 1991 to 2001 -79.97, Dugi Rat - 70.47, Klis - 67.90, Split - 63.35, Kaštela - 59.24, Podstrana - 47.21, Solin - 43.82) and in the Makarska coast which has highly developed tourism and is a traditionally popular area for second home owners (e.g. Gradac -84.79, Podgora - 73.06, Brela - 66.87, Makarska - 49.49). The reason for the steep decrease in the number of second homes in the areas which were strong receiving second home areas until recently must be sought in the sudden increase of the temporarily unoccupied dwellings, which implies that a considerable number of dwellings which are de facto used for vacation and recreation are "hidden" in the totality of the category of temporarily unoccupied dwellings. In addition, the Makarska coast, primarily its southern part, which registered the highest decrease in the number of second homes (the municipalities of Gradac and Podgora), is a traditionally strong receiving second home area for the inhabitants of the nearby Bosnia and Herzegovina many of which decided after the collapse of Yugoslavia to sell their real estate, and which were in turn then registered as "dwellings used only for commercial purposes" or "temporarily unoccupied dwellings".

The insular part of the Split-Dalmatia county did not register a more discernable decrease in the number of dwellings for vacation and recreation from 1991 to 2001. Thus despite the existence of several units of local self-government with the lower number of second homes in 2001 than in 1991 (e.g.. Selca - index for the change in the number of second dwellings from 1991 to 2001 - 96.99, Šolta - 89.60, Stari Grad - 86.61), it can be claimed that the area registers slight increase in their number. The most noticeable positive value of the index for the change in the number of second homes from 1991 to 2001 is found in the towns/municipalities of the island of Brač, e.g. Postira (166.01), Bol (157.30), Supetar (132.07), Pučišća (131.39), as well as in the Town of Vis (123.44).

The southernmost part of the Croatian littoral, the area of Southern Dalmatia, registered in the period from 1991 to 2001 the decrease in the number of second homes in almost all of its territory. A considerable part of this area was occupied or suffered considerable damage during the Homeland War, which is certainly one of the reasons for the decrease in the number of second homes between 1991 and 2001. Other reasons include: the sale of real estate owned by citizens of other republics of the former Yugoslavia which made up a significant proportion of second home owners in the area, and the registration of second 
homes as temporarily unoccupied dwellings. The number of dwellings for vacation and recreation registered steepest decrease in the following towns/municipalities: Slivno (index for the change in the number of second homes from 1991 to 2001. - 72.85), Ston (69.76), Dubrovnik (49.81), Dubrovačko primorje (45.49), Janjina (45.11), Konavle (35.28) and Ploče (23.63). However, the trend towards the increase in the number of second homes in the last inter-census period is noticeable throughout most of the largest island of Korčula (Lumbarda - index for the change in the number of second homes from 1991 to 2001 -171.08, Blato - 146.20, Vela Luka - 129.49, the Town of Korčula-125.19), the island of Lastovo (115.32) and in the Municipality of Trpanj on the Pelješac peninsula (120.14).

\section{SPATIAL DISTRIBUTION OF DWELLINGS FOR VACATION AND RECREATION IN CROATIA IN 2001}

The Census of Population, Households and Dwellings from 2001 records 182513 dwellings for vacation and recreation in Croatia. They represented $9.72 \%$ of all dwellings in Croatia or 12.84 dwellings for vacation and recreation for every 100 permanently inhabited dwellings. In other words, approximately every tenth dwelling in Croatia is used as a secondary recreational dwelling. What is their spatial distribution on the level of counties (Fig. 3)?

The counties with the access to sea, i.e. the counties of the Croatian littoral, stand out in terms of the number of dwellings for vacation and recreation. Those among them with largest numbers of second dwellings are Primorje-Gorski kotar, Zadar and Split-Dalmatia counties with over 20000 secondary dwellings in 2001. Istria and Šibenik-Knin counties with over 10000 dwellings for vacation and recreation also belong to the upper half of the chart. The other two counties with access to sea, Lika-Senj and Dubrovnik-Neretva, record a slightly lower number of dwellings for vacation and recreation in comparison with other counties of the Croatian littoral.

This order of coastal counties can be explained by the relative proximity to the emissive urban region of Zagreb, the primary emissive second home area in Croatia but also proximity to Slovenia, a traditionally significant international emissive area. Further, the Primorje-Gorski kotar county includes the city of Rijeka, a macro-regional centre and an important "reservoir" of tourist demand. The Zadar county is "popular" among second home population also because of the relative proximity to Zagreb, while the demonstrably high number of secondary dwellings in the slightly more distant Split-Dalmatia county can be explained by the large number of receiving settlements in the county, by the high demand for second homes in the macro-regional centre of Split and its environs, and by the proximity to Bosnia and Herzegovina (the Makarska coast, the island of Čiovo) and by the traditional concentration of their second home population in the territory of the county. Due to the relative distance from Zagreb, the primary emissive second home area in Croatia, a slightly lower number of dwellings for vacation and recreation is found in the Istria and Sibenik-Knin counties. The Istria county is also characteristic of the international character of its second home population which is dominated by second home owners from the nearby Slovenia. The slightly lower number of second homes in the Šibenik-Knin county can be explained by the relatively shorter coastal area it includes which limits the number of 
locations suitable for second homes. The less discernable presence of secondary dwellings in the Lika-Senj county is the consequence of the shorter coastal line with fewer receiving areas suitable for second homes and of somewhat less favourable climate (frequent bora blowing in the canal at the foothold of Mt. Velebit). The Dubrovnik-Neretva county is geographically farthest and with poorer road communication with domestic and foreign emissive regions which is the main reason for its "falling behind" in the number of second homes in comparison with other counties of the Croatian littoral.

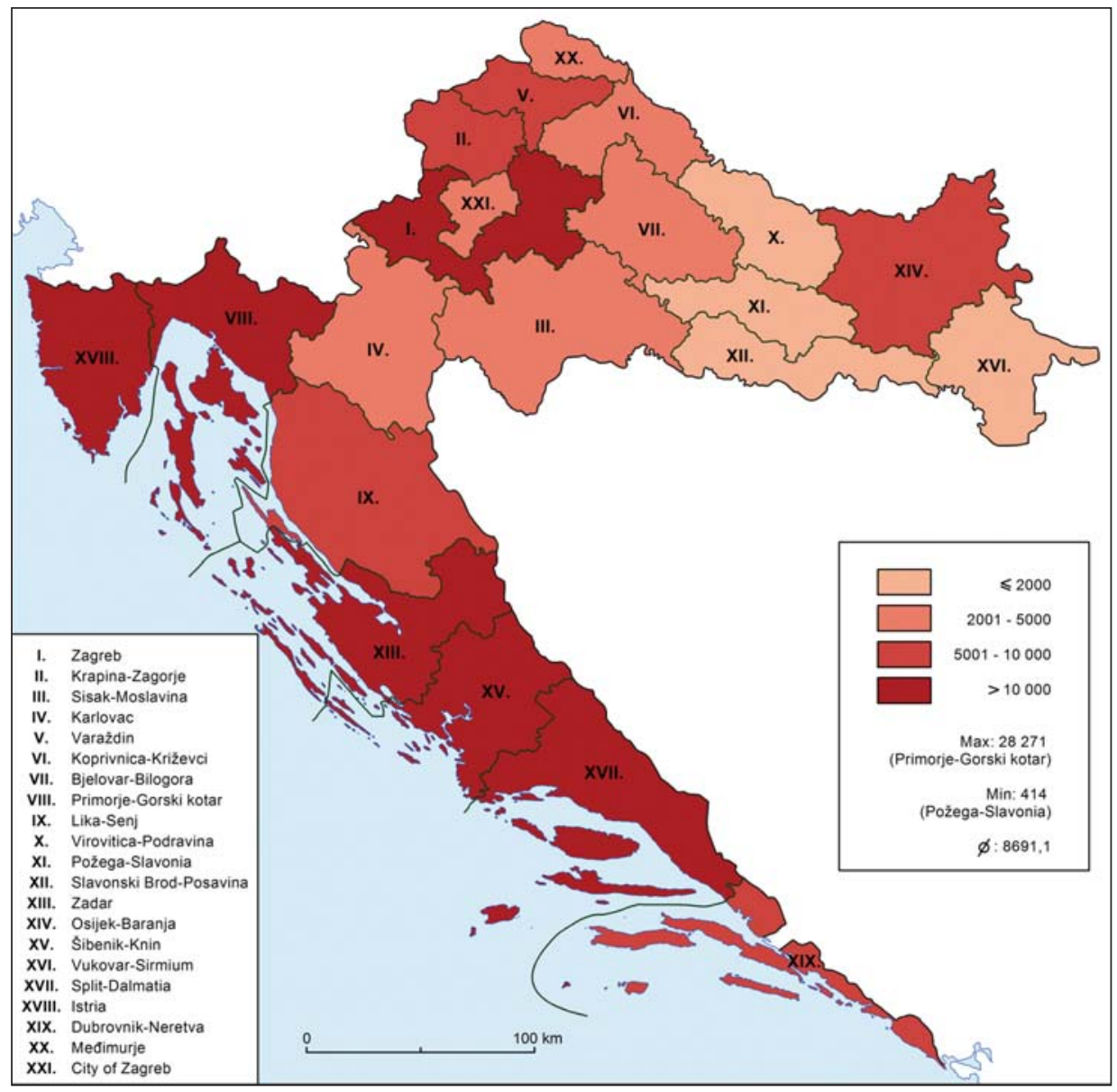

Fig. 3 The number of dwellings for vacation and recreation in 2001, by counties

Sl. 3. Broj stanova za odmor i rekreaciju po županijama 2001. godine

Source: Census of Population, Households and Dwellings $31^{\text {st }}$ March 2001, Dwellings according to the manner of use by towns/municipalities, Second edition, Central Bureau of Statistics of the Republic of Croatia, Zagreb, 2003.

http://www.dzs.hr/Popis\%202001/popis20001. htm

Although these counties of the Croatian littoral have a higher number of second homes, the second home phenomenon is also characteristic of the continental Croatian counties. 
Most prominent among them are those counties which include attractive hilly terrain or mountainous recreational areas in the vicinity of larger cities in the inland, particularly Zagreb (the Zagreb county with over 15000 dwellings for vacation and recreation occupies the fourth place within Croatia; Krapina-Zagorje, Varaždin, Sisak-Moslavina, Karlovac, Koprivnica-Križevci) and Osijek (Osijek-Baranja). As can be expected, the lowest number of second homes is found in counties located in the recreationally less attractive flat areas which are at the same time farther away from larger cities and towns, i.e. from the centres of demand for second homes (e.g. Slavonski Brod-Posavina, Vukovar-Sirmium, ViroviticaPodravina, Požega-Slavonia counties).

Tab. 1 The number of dwellings for vacation and recreation and permanently occupied dwellings in 2001, by counties

Tab. 1. Broj stanova za odmor i rekreaciju i stalno nastanjenih stanova po županijama 2001. godine

\begin{tabular}{|c|c|c|c|}
\hline County & $\begin{array}{c}\text { Number of } \\
\text { dwellings for } \\
\text { vacation and } \\
\text { recreation }\end{array}$ & $\begin{array}{l}\text { Number of } \\
\text { permanently } \\
\text { occupied } \\
\text { dwellings }\end{array}$ & $\begin{array}{l}\text { Number of dwellings for } \\
\text { vacation and recreation } \\
\text { per } 100 \text { permanently } \\
\text { occupied dwellings }\end{array}$ \\
\hline Zadar & 25305 & 50622 & 49.99 \\
\hline Šibenik-Knin & 14468 & 38467 & 37.61 \\
\hline Lika-Senj & 7096 & 19072 & 37.21 \\
\hline Primorje-Gorski kotar & 28271 & 108662 & 26.02 \\
\hline Krapina-Zagorje & 9916 & 42402 & 23.39 \\
\hline Istria & 14696 & 70562 & 20.83 \\
\hline Zagreb & 16528 & 91376 & 18.09 \\
\hline Split-Dalmatia & 22498 & 138491 & 16.25 \\
\hline Dubrovnik-Neretva & 5559 & 37346 & 14.89 \\
\hline Koprivnica-Križevci & 4668 & 38215 & 12.22 \\
\hline Karlovac & 4691 & 47839 & 9.81 \\
\hline Varaždin & 5055 & 53852 & 9.39 \\
\hline Sisak-Moslavina & 4900 & 60541 & 8.09 \\
\hline Bjelovar-Bilogora & 3239 & 43091 & 7.52 \\
\hline Međimurje & 2332 & 34243 & 6.81 \\
\hline Osijek-Baranja & 5340 & 107987 & 4.95 \\
\hline Slavonski Brod-Posavina & 1175 & 52178 & 2.25 \\
\hline Virovitica-Podravina & 581 & 30372 & 1.91 \\
\hline City of Zagreb & 4843 & 271183 & 1.79 \\
\hline Požega-Slavonia & 414 & 25975 & 1.59 \\
\hline Vukovar-Sirmium & 938 & 59147 & 1.59 \\
\hline TOTAL & 182513 & 1421623 & 12.84 \\
\hline
\end{tabular}

Source: Census of Population, Households and Dwellings $31^{\text {st }}$ March 2001, Dwellings according to the manner of use by towns/municipalities, Second edition, Central Bureau of Statistics of the Republic of Croatia, Zagreb, 2003.

http://www.dzs.hr/Popis\%202001/popis20001. htm 
An ever more realistic picture of the spatial distribution of dwellings for vacation and recreation and of its import for the overall number of dwellings in Croatian counties is gathered by comparing the number of dwellings for vacation and recreation and the number of permanently occupied dwellings (Tab. 1).

According to the mentioned criterion, the first place among Croatian counties is occupied by the Zadar county with one dwelling for vacation and recreation for every two permanently occupied dwellings. All counties with access to sea score above the Croatian average (12.84 dwellings for vacation and recreation for 100 permanently occupied dwellings) but only two continental counties, Krapina-Zagorje and Zagreb. Due to the presence of larger urban centres with the highest number of permanently occupied dwellings, the Primorje-Gorski kotar, Split-Dalmatia and Osijek-Baranja counties, and especially the City of Zagreb, are ranked considerably lower than in the presentation of the absolute number of dwellings for vacation and recreation. On the other hand, when this criterion is applied to the counties with a relatively high number of second homes and with somewhat smaller population centres (eg. Šibenik-Knin, Lika-Senj, Krapina-Zagorje), which also implies a lower number of permanently occupied dwellings, they rank higher on the list. The reasons for this spatial distribution are identical with the reasons mentioned with regard to the analysis of spatial distribution of dwellings for vacation and recreation in Croatian counties.

Tab. 2 The number of dwellings for vacation and recreation in coastal, insular and continental areas of counties of the Croatian littoral and in Croatia as a whole in 2001

Tab. 2. Broj stanova za odmor i rekreaciju u obalnom, otočnom i kontinentalnom dijelu hrvatskih priobalnih županija te Hrvatske u cjelini 2001. godine

\begin{tabular}{|c|c|c|c|c|c|c|c|c|}
\hline County & Coast & $\mathbf{\%}$ & Islands & $\mathbf{\%}$ & Continent & $\mathbf{\%}$ & Total & $\%$ \\
\hline $\begin{array}{c}\text { Primorje- } \\
\text { Gorski kotar }\end{array}$ & 9889 & 34.98 & 16103 & 56.96 & 2279 & 8.06 & 28271 & 100 \\
\hline Zadar & 10843 & 42.85 & 13826 & 54.64 & 636 & 2.51 & 25305 & 100 \\
\hline $\begin{array}{c}\text { Split- } \\
\text { Dalmatia }\end{array}$ & 7314 & 32.51 & 11761 & 52.28 & 3423 & 15.21 & 22498 & 100 \\
\hline Istria & 13284 & 90.39 & 0 & 0 & 1412 & 9.61 & 14696 & 100 \\
\hline $\begin{array}{c}\text { Sibenik- } \\
\text { Knin }\end{array}$ & 9931 & 68.64 & 3228 & 22.31 & 1309 & 9.05 & 14468 & 100 \\
\hline $\begin{array}{c}\text { Lika-Senj } \\
\text { Dubrovnik- } \\
\text { Neretva }\end{array}$ & 3740 & 52.71 & 2378 & 33.51 & 978 & 13.78 & 7096 & 100 \\
\hline TOTAL & $\mathbf{5 7 8 8 7}$ & $\mathbf{4 9 . 1 0}$ & $\mathbf{4 9 8 5 4}$ & $\mathbf{4 2 . 2 9}$ & $\mathbf{1 0 1 5 2}$ & $\mathbf{8 . 6 1}$ & $\mathbf{1 1 7 8 9 3}$ & $\mathbf{1 0 0}$ \\
\hline $\begin{array}{c}\text { TOTAL } \\
\text { (CROATIA) }\end{array}$ & $\mathbf{5 7 8 8 7}$ & $\mathbf{3 1 . 7 2}$ & $\mathbf{4 9 8 5 4}$ & $\mathbf{2 7 . 3 2}$ & $\mathbf{7 4 7 7 2}$ & $\mathbf{4 0 . 9 7}$ & $\mathbf{1 8 2 5 1 3}$ & $\mathbf{1 0 0}$ \\
\hline
\end{tabular}

Source: Census of Population, Households and Dwellings $31^{\text {st }}$ March 2001, Dwellings according to the manner of use by towns/municipalities, Second edition, Central Bureau of Statistics of the Republic of Croatia, Zagreb, 2003.

http://www.dzs.hr/Popis\%202001/popis20001.htm 
Similar conclusions are reached when the total territory of Croatia is divided into the coastal, insular and continental parts. According to this country-wide analysis, the Croatian littoral occupies the leading position in the country as regards the concentration of dwellings for vacation and recreation although not by as much as might be expected. In 2001, the Croatian coast and islands "hosted" 107 941, i.e. 59.03\% second homes in Croatia, while the continental part of the country had 74772 , i.e. $40.97 \%$ of all dwellings for vacation and recreation in the country. Here we can also point out a slight advantage of the coastal area over the islands (Tab. 2).

If only counties of the Croatian littoral are taken into account, i.e. those seven counties with access to sea, $91.39 \%$ second homes are concentrated in their coastal and insular parts, and only $8.61 \%$ of the secondary recreational dwellings are located in their continental parts. These statistics point to the conclusion that the spatial distribution of second homes on the national level reveals relative dispersion, which stands in stark contrast with the leading receiving second home area, the Croatian littoral, and which manifests the trend towards the concentration of second homes in the coastal region due to the attractiveness of the sea as the primary drawing factor.

Tab. 3 The number of dwellings for vacation and recreation in coastal, insular and continental areas of counties of the Croatian littoral and in Croatia as a whole in 1971

Tab. 3. Broj stanova za odmor i rekreaciju u obalnom, otočnom i kontinentalnom dijelu hrvatskih priobalnih županija te Hrvatske u cjelini 1971. godine

\begin{tabular}{|c|c|c|c|c|c|c|c|c|}
\hline County & Coast & $\mathbf{\%}$ & Islands & $\mathbf{\%}$ & Continent & $\mathbf{\%}$ & Total & $\%$ \\
\hline $\begin{array}{c}\text { Primorje- } \\
\text { Gorski kotar }\end{array}$ & 2393 & 37.73 & 3633 & 57.28 & 316 & 4.98 & 6342 & 100 \\
\hline $\begin{array}{c}\text { Split- } \\
\text { Dalmatia }\end{array}$ & 1580 & 40.43 & 2197 & 56.22 & 131 & 3.35 & 3908 & 100 \\
\hline $\begin{array}{c}\text { Šibenik- } \\
\text { Knin }\end{array}$ & 1516 & 59.87 & 947 & 37.40 & 69 & 2.73 & 2532 & 100 \\
\hline Istria & 2203 & 94.79 & 0 & 0 & 121 & 5.21 & 2324 & 100 \\
\hline Zadar & 1156 & 52.26 & 899 & 40.64 & 157 & 7.10 & 2212 & 100 \\
\hline $\begin{array}{c}\text { Dubrovnik- } \\
\text { Neretva }\end{array}$ & 970 & 58.75 & 680 & 41.19 & 1 & 0.06 & 1651 & 100 \\
\hline Lika-Senj & 380 & 56.05 & 162 & 23.89 & 136 & 20.06 & 678 & 100 \\
\hline $\begin{array}{c}\text { TOTAL } \\
\text { TOTOTAL }\end{array}$ & $\mathbf{1 0 1 9 8}$ & $\mathbf{5 1 . 9 1}$ & $\mathbf{8 5 1 8}$ & $\mathbf{4 3 . 3 6}$ & $\mathbf{9 3 1}$ & $\mathbf{4 . 7 4}$ & $\mathbf{1 9 6 4 7}$ & $\mathbf{1 0 0}$ \\
\hline $\begin{array}{c}\text { TO198 } \\
\text { (CROATIA) }\end{array}$ & $\mathbf{4 4 . 4 4}$ & $\mathbf{8 5 1 8}$ & $\mathbf{3 7 . 1 2}$ & $\mathbf{4 2 3 0}$ & $\mathbf{1 8 . 4 3}$ & $\mathbf{2 2 9 4 6}$ & $\mathbf{1 0 0}$ \\
\hline
\end{tabular}

Source: Census of Population and Dwellings 1971, Dwellings for vacation and recreation. Statistics by settlements and municipalities, Book 6, Federal Bureau of Statistics, Beograd, 1973.

All counties of the Croatian littoral with the exception of Lika-Senj and Split-Dalmatia record over $90 \%$ of second homes in their coastal and insular parts, i.e. in the littoral. The relatively less prominent concentration of second homes in the littoral part of the Lika-Senj county can be explained by a relatively smaller proportion of the territory of the county 
which belongs to the littoral. In the Split-Dalmatia county the sudden population drain from its spacious hinterland, i.e. its continental part (Dalmatinska zagora), effected the conversion (real as well as fiscal) of a significant proportion of all formerly permanently occupied dwellings into dwellings for vacation and recreation.

While the statistics for 1981 and 1991 show the distribution of second homes similar to that of 2001, the statistics about the number of second homes in the coastal, insular and continental parts of Croatia gathered during the first census by counting dwellings for vacation and recreation in Croatia in 1971, point to the conclusion that the spatial distribution of second homes on national and county levels in the last forty years underwent significant changes (Tab. 3).

In 1971 even $81.57 \%$ of all dwellings for vacation and recreation in Croatia were concentrated on the Croatian coast and islands, which points to the more prominent concentration of second homes than in 2001 (59.03\%). It is obvious that the importance of the coastal receiving second home areas in those times, according to the relevant indications, was considerably higher than in the times of the most recent census. Since then secondary dwelling has been gradually spreading into the later "discovered" continental second home areas. Then, same as today, and considering the distribution of secondary dwellings in the Croatian littoral, there were more second homes in the coastal part than in the insular part. In 1971, same as in 2001, and considering the distribution of second dwellings in the counties of the Croatian littoral, the highest number of second homes was found in their coastal and insular part with a high proportion figures favouring this part of the littoral (with 95.26\% dwellings for vacation and recreation in the coastal and insular part and only $4.74 \%$ in the immediate continental hinterland).

Taking into account possible exceptions, even a cursory glance at the statistics on the county level implies that the early, coastal concentrations of second homes in the decades after 1971 served as centres from which second homes spread and started to "conquer" attractive parts of the hinterland of the counties of the Croatian littoral (with only $4.74 \%$ of second homes in the continental part of the counties of the Croatian littoral in 1971, while in 2001 the same territory registered $8.61 \%$ of all second homes in the counties of the Croatian littoral).

\section{SPATIAL DISTRIBUTION OF DWELLINGS FOR VACATION AND RECREATION IN THE CROATIAN LITTORAL IN 2001}

The spatial distribution of dwellings for vacation and recreation in 2001 shows the persistence, in the last inter-census period (1991 - 2001), of earlier trends for the concentration of secondary dwelling in the leading tourist areas of the Croatian littoral, but also the gradually increasing dispersion into areas which are not so attractive as tourist destinations but are attractive for second home owners because the real estate prices are often more agreeable there. This has created a partial discrepancy between the main tourist and second home areas in the Croatian littoral. In addition, due to the stagnation and the decrease in the number of second homes in the larger part of Dalmatia, the receiving second home areas of Istria and the Kvarner have again developed into leading receiving second 
home areas of the coastal part of Croatia even though not to the same degree as before the second home "boom" in Dalmatia in 1970s and 1989s (Fig. 4).

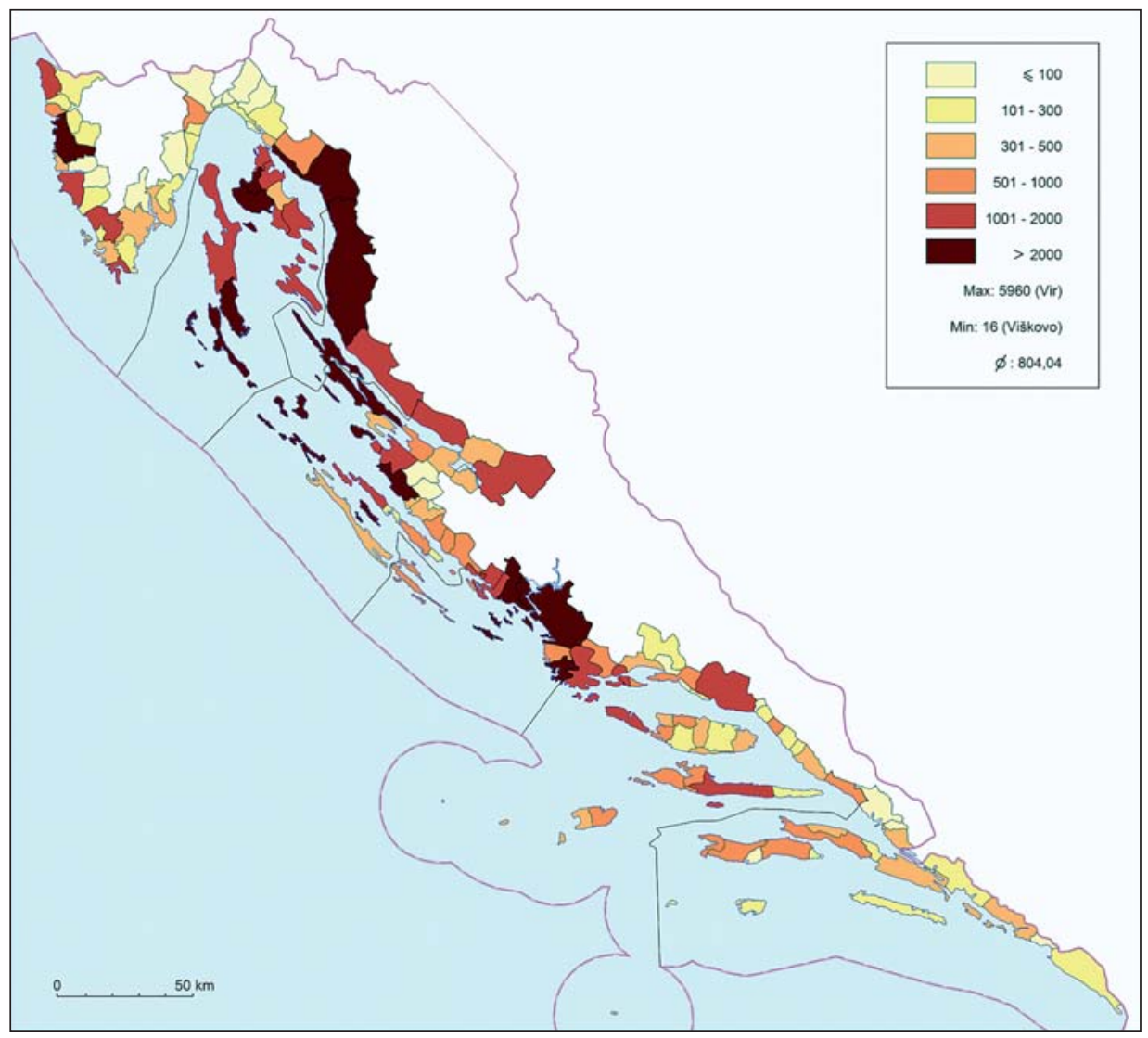

Fig. 4 The number of dwellings for vacation and recreation in the towns and municipalities of the Croatian littoral in 2001

Sl. 4. Broj stanova za odmor i rekreaciju u gradovima i općinama priobalnoga dijela Hrvatske 2001. godine

Source: Census of Population, Households and Dwellings 31 $1^{\text {st }}$ March 2001, Dwellings according to the manner of use by towns/municipalities, Second edition, Central Bureau of Statistics of the Republic of Croatia, Zagreb, 2003.

http://www.dzs.hr/Popis\%202001/popis20001. htm

According to the outcome of the Census of Population, Households and Dwellings from 2001, the average number of dwellings for vacation and recreation in 134 towns/ municipalities in the Croatian littoral totalled 804.04 which is somewhat higher than in 1991 (728.67). The numbers ranged from 5960 registered on Vir and 16 in Viškovo in the hinterland of Rijeka. Same as ten years earlier, the second home phenomenon was documented in all units of local self-government in the Croatian littoral, which means that, despite stagnation in the tumultuous 1990s, secondary dwelling retained the epithet 
of one of the most remarkable phenomena in the everyday life of the coastal and insular region of Croatia.

Nevertheless, with the exception of the main emissive second home areas in the extreme south region of South Croatia (the Dubrovnik-Neretva county, the Makarska coast, Mid-Dalmatian islands) with traditionally lower number of dwellings for vacation and recreation, and the leading receiving areas of the Kvarner, North Dalmatia and the Western coast of Istria, which had a high concentration of second dwellings even in earlier times, the spatial distribution of dwellings for vacation and recreation in 2001 did not reveal any spatial regularity.

Because of these reasons the list of fourteen highest ranked towns/municipalities of the Croatian littoral with over 2000 dwellings for vacation and recreation in 2001 demonstrates a certain variety in spatial distribution with slight prevalence of units of local self-government from the Kvarner, North Dalmatia and the Western coast of Istria. The following towns/municipalities of the Croatian littoral had over 2000 registered dwellings for vacation and recreation in 2001: Vir (5960), Crikvenica (4121), Poreč (3456), Šibenik (3375), Mali Lošinj (2936), Vodice (2780), Novi Vinodolski (2729), Pag (2720), Senj (2550), Zadar (2394), Novalja (2378), Krk (2303), Malinska-Dubašnica (2283) and Rogoznica (2259).

The leading receiving second home areas in the Croatian littoral have generally remained unchanged in comparison with earlier censuses. The towns/municipalities of the Western coast of Istria with the highest number of dwellings for rest and recreation in 2001 were: Poreč - 3456 dwellings for vacation and recreation, Umag - 1926, Vodnjan (due to the apartment village Barbariga) - 1343, Medulin - 1330 and Rovinj - 1065. In the Crikvenica-Vinodol coast these were: Crikvenica - 4121 and Novi Vinodolski - 2729; on the Kvarner islands: Mali Lošinj - 2936, Krk - 2303, Malinska-Dubašnica - 2283, Omišalj - 1605, Cres - 1507, Rab - 1448, Dobrinj - 1303, Punat - 1138 and Baška - 1102; in the Velebit coast: Senj-2550, Starigrad - 1396 and Karlobag - 1190; in the coast of the Novigrad and Karin sea: Obrovac - 1249; on the North Dalmatian islands: Vir - 5960, Pag - 2720, Novalja - 2378 and Preko - 1037, in the northern part of the Zadar coast: Zadar - 2394, Nin - 1461 and Privlaka - 1075, in the Šibenik coast: Šibenik - 3375, Vodice - 2780, Rogoznica - 2259, Pirovac - 1791 and Tisno - 1331; in the wider area of Trogir with the island of Čiovo: Okrug - 1377, Marina - 1284 and Trogir - 1061; in the Omiš coast: Omiš - 1745, while the municipalities of the Middle Dalmatian islands with the highest number of second dwellings were Šlta -1159 and Jelsa - 1131 .

In contrast to earlier censuses, the spatial distribution of dwellings for vacation and recreation in 2001 was largely influenced, in addition to the physical and temporal distance from the most important emissive areas of Croatia (primarily Zagreb and regional centres of Central Croatia) and to the specific micro-geographic factors (such as the recreational possibilities of the receiving area, the relation between offer and demand on the local real estate market of the receiving second home area, the development of infrastructure, etc.), by parameters such as the accepted practice of registering second homes as "permanently occupied dwellings", "temporarily occupied dwellings" or "dwellings used exclusively for commercial purpose", and the exposure to devastation during the Homeland War. 


\section{SPATIAL DISTRIBUTION OF DWELLINGS FOR VACATION AND RECREATION ON CROATIAN ISLANDS IN 2001}

The spatial distribution of dwellings for vacation and recreation on Croatian islands in 2001 was primarily dependant on their distance from the mainland, that is the frequency of ferry and catamaran connections with the mainland. That is why the islands, which were connected with the mainland by a bridge, in 2001 occupied highest places on the list of presenting the number of dwellings for vacation and recreation (1 Krk 10212 second homes, 2 Vir - 5960, 3 Pag - 5572, 7 Čiovo - 2058, 9 Murter - 2042). In addition to these, the other islands ranked among the first ten according to the number of dwellings for vacation and recreation are: 4 Brač (3887), 5 Hvar (3014), 6 Korčula (2062), 8 Lošinj (2050) and 10 Cres (1778). These are islands with relatively largest territory and the higher number of inhabitants, as well as with better connections with the mainland.

The uneven development of the second home phenomenon in the Croatian littoral in the inter-census period between 1991 and 2001 has had significant influence on the spatial distribution of dwellings for vacation and recreation on large groups of islands (Tab. 4).

Tab. 4 The number of dwellings for vacation and recreation and permanently occupied dwellings in 2001, by large groups of islands

Tab. 4. Broj stanova za odmor i rekreaciju i stalno nastanjenih stanova po velikim otočnim skupinama 2001. godine

\begin{tabular}{|c|c|c|c|c|c|}
\hline $\begin{array}{c}\text { Large } \\
\text { groups of } \\
\text { islands }\end{array}$ & $\begin{array}{c}\text { Number } \\
\text { of islands }\end{array}$ & $\begin{array}{c}\text { Territory of } \\
\left.\text { islands } \mathbf{( k m}^{\mathbf{2}}\right)\end{array}$ & $\begin{array}{c}\text { Number of } \\
\text { inhabitants }\end{array}$ & $\begin{array}{c}\text { Number of } \\
\text { second homes }\end{array}$ & $\begin{array}{c}\text { Number of } \\
\text { permanently occupied } \\
\text { dwellings }\end{array}$ \\
\hline Kvarner & 9 & 1005.73 & 38687 & 16103 & 13600 \\
\hline $\begin{array}{c}\text { North } \\
\text { Dalmatian }\end{array}$ & 24 & 751.19 & 28865 & 19432 & 10366 \\
\hline $\begin{array}{c}\text { Middle } \\
\text { Dalmatian }\end{array}$ & 9 & 890.85 & 35859 & 11761 & 12620 \\
\hline $\begin{array}{c}\text { South } \\
\text { Dalmatian }\end{array}$ & 6 & 446.78 & 19007 & 2558 & 6155 \\
\hline TOTAL & $\mathbf{4 8}$ & $\mathbf{3 0 9 4 . 5 5}$ & $\mathbf{1 2 2 4 1 8}$ & $\mathbf{4 9 8 5 4}$ & $\mathbf{4 2 7 4 1}$ \\
\hline
\end{tabular}

Sources: Census of Population, Households and Dwellings $31^{\text {st }}$ March 2001, Population by presence/absence by settlements, Second edition, Central Bureau of Statistics of the Republic of Croatia, Zagreb, 2003. http://www.dzs.hr/Popis\%202001/popis20001.htm

Census of Population, Households and Dwellings $31^{\text {st }}$ March 2001, Dwellings according to the manner of use by settlements, Internal information, Central Bureau of Statistics of the Republic of Croatia, Zagreb, 2003.

The continuation of the growth of secondary dwelling on the North Dalmatian islands (especially on Vir - the growth of $61.87 \%$ on an island with the already high concentration of second homes, and on Pag - the growth of 30.07\%) and the Kvarner islands (on Lošinj - the growth of $45.80 \%$ and on Krk, still the leader among Croatian islands according to the number of dwellings for vacation and recreation - the growth of $38.39 \%$ ), along with the stagnation on Middle Dalmatian islands and a modest increase of secondary dwelling on the least exposed South Dalmatian islands, had resulted in the conspicuous advantage of the first two groups of islands in the number of second homes. 
The islands of the North Dalmatia (Vir - 5960 dwellings for vacation and recreation, Pag - 5572, Murter - 2042, Ugljan - 1402 and Pašman - 1221) registered in 2001 more second homes than any other large group of islands (38.98\% of all second homes in the insular part of Croatia), although the relative increase was highest on the islands of the Kvarner ${ }^{11}$, somewhat farther away from the areas afflicted by war operations, which at the same time registered $32.30 \%$ dwellings for vacation and recreation (Krk - 10212 , Lošinj - 2050, Cres - 1778 and Rab - 1448). Next came the Middle Dalmatian group of islands with 23.59\% dwellings for vacation and recreation (Brač - 3887, Hvar - 3014, Čiovo - 2058, Vis - 1232 and Šolta - 1155), while the bottom of the list of the four groups of islands according to the number of dwellings for vacation and recreation in 2001 was occupied by the South Dalmatian islands with $5.13 \%$ of all second homes on Croatian islands (Korčula-2062).

In 2001 there were more dwellings for vacation and recreation registered on Croatian islands than there were permanently occupied dwellings. This indicates that the processes fostering the increase in the tourism-recreational function of islands, which started before this time, still go on accompanied by the decrease in the employment-residence function (with intense depopulation on the majority of Croatian islands). All this supports the inference that the insular territory of Croatia, with the emergence and intensive development of tourism and the second home phenomenon, gradually transforms itself from a production area into consumption area, the phenomenon common to numerous receiving second home areas in Europe and the world.

The comparison between the number of dwellings for vacation and recreation and the number of permanently occupied dwellings registered in 2001 will be presented, and the islands will be divided into main groups according to their relative distance from the mainland (Tab. 5).

Tab. 5 The number of dwellings for vacation and recreation and the number of permanently occupied dwellings in 2001, by groups of islands in relation to their location vis-à-vis the mainland

Tab. 5. Broj stanova za odmor i rekreaciju i stalno nastanjenih stanova po otočnim skupinama prema položaju u odnosu na kopno 2001. godine

\begin{tabular}{|c|c|c|c|c|c|}
\hline $\begin{array}{c}\text { Groups of } \\
\text { islands by } \\
\text { location }\end{array}$ & $\begin{array}{c}\text { Number of } \\
\text { islands }\end{array}$ & $\begin{array}{c}\text { Territory of } \\
\left.\text { islands } \mathbf{( k m}^{2}\right)\end{array}$ & $\begin{array}{c}\text { Number of } \\
\text { inhabitants }\end{array}$ & $\begin{array}{c}\text { Number } \\
\text { of second } \\
\text { homes }\end{array}$ & $\begin{array}{c}\text { Number of } \\
\text { permanently } \\
\text { occupied } \\
\text { dwellings }\end{array}$ \\
\hline Coastal & 20 & 1471,05 & 74505 & 36367 & 26089 \\
\hline Channel & 14 & 1263,39 & 40823 & 10365 & 13864 \\
\hline Open sea & 14 & 360,11 & 7090 & 3122 & 2788 \\
\hline TOTAL & $\mathbf{4 8}$ & $\mathbf{3 0 9 4 , 5 5}$ & $\mathbf{1 2 2 4 1 8}$ & $\mathbf{4 9 8 5 4}$ & $\mathbf{4 2 7 4 1}$ \\
\hline
\end{tabular}

Sources: Census of Population, Households and Dwellings $31^{\text {st }}$ March 2001, Population by presence/absence by settlements, Second edition, Central Bureau of Statistics of the Republic of Croatia, Zagreb, 2003. http://www.dzs.hr/Popis\%202001/popis20001.htm

Census of Population, Households and Dwellings $31^{\text {st }}$ March 2001, Dwellings according to the manner of use by settlements, Internal information, Central Bureau of Statistics of the Republic of Croatia, Zagreb, 2003. 
The dominance of largest, most densely populated islands, islands closest to the mainland and islands with best traffic communication with the mainland (frequent ferry and catamaran connections, bridges) in relation to the number of dwellings for vacation and recreation has remained constant until the present time. Moreover, in comparison with 1991 it has even increased in relation to the other two groups of islands (the increase by $23.98 \%$ in the period of a decade). On the islands closest to the mainland there were, in 2001,36367 second homes or $72.95 \%$ dwellings for vacation and recreation on all Croatian islands (in 1991 there were 29232 second homes or 70.76\%). Among the coastal Croatian islands the highest number of dwellings for vacation and recreation was registered on: Krk (10 212 second homes), Vir (5960), Pag (5572), Brač (3887), Čiovo (2058) and Murter (2042). The 2001 census registered more dwellings for vacation and recreation (36 367) than permanently occupied dwellings (26 089) on coastal islands. Taking into account the higher density of population and the more successful economic development of coastal islands, the above disparity is the consequence of the rapid development of the second home phenomenon based on the comparative advantages of their location in relation to the mainland and the leading emissive second home areas rather than a reflection of intense process of depopulation.

On the channel islands, which are farther away from the mainland and not so densely populated, the last census of 2001 registered 10365 dwellings for vacation and recreation (20.79\% of all second homes on Croatian islands), which leads to the conclusion that, despite the increase in this area by $16.23 \%$, but because of the stronger increase of second homes in the coastal islands from 1991 to 2001, the ratio of second homes on channel islands actually decreased (in 1991 they housed $21.59 \%$ of all second dwellings on Croatian islands). Secondary dwelling on the islands of this group of islands showed to be prominent primarily on larger and more densely populated islands: Hvar (3014 dwellings for vacation and recreation), Korčula (2062), Lošinj (2050) and Cres (1778). The predominance of permanently occupied dwellings (13 864) over dwellings for vacation and recreation (10 365) in this group of islands, which continued in 2001, is a reflection of the less favourable location for second homes, but also of the relatively strong function of permanent occupancy in the conditions of depopulation (emigration and aging), which spreads more intensely on smaller and less densely populated islands - not only of this group of islands but also of the whole insular territory of Croatia.

As in 1991, the depopulation indicators were most evident on Croatian open sea islands which are farthest away from the mainland and least densely populated. Despite the fact that the second home phenomenon is not so developed there, the number of dwellings for vacation and recreation was higher than the number of permanently occupied dwellings, which is the indication of their strong depopulation rather than of stronger concentration of dwellings of secondary recreational function. Moreover, in the period from 1991 to 2001 the number of second homes on the open sea islands decreased by $1.20 \%$. In 2001 the total of 3122 dwellings for vacation and recreation were registered on the open sea islands, or only $6.26 \%$ of all second homes on Croatian islands. The highest number of second homes was found on the following open sea islands: Vis (1232 dwellings for vacation and recreation), Silba (443), Dugi otok (371) and Susak (283). 


\section{THE DENSITY OF DWELLINGS FOR VACATION AND RECREATION IN THE CROATIAN LITTORAL IN 2001}

The only slightly higher average density index registered in 2001 for dwellings for vacation and recreation in towns/municipalities of the Croatian littoral in comparison with the situation ten years earlier (8.56 second homes $/ \mathrm{km}^{2} 1991$ vs. 9.58 dwellings for vacation and recreation $/ \mathrm{km}^{2}$ in 2001) also corroborates the claim, based on all the reasons already mentioned, about the general stagnation, or rather a small increase, of the second home phenomenon in the Croatian littoral in the last turbulent inter-census period (1991 - 2001) (Fig. 5).

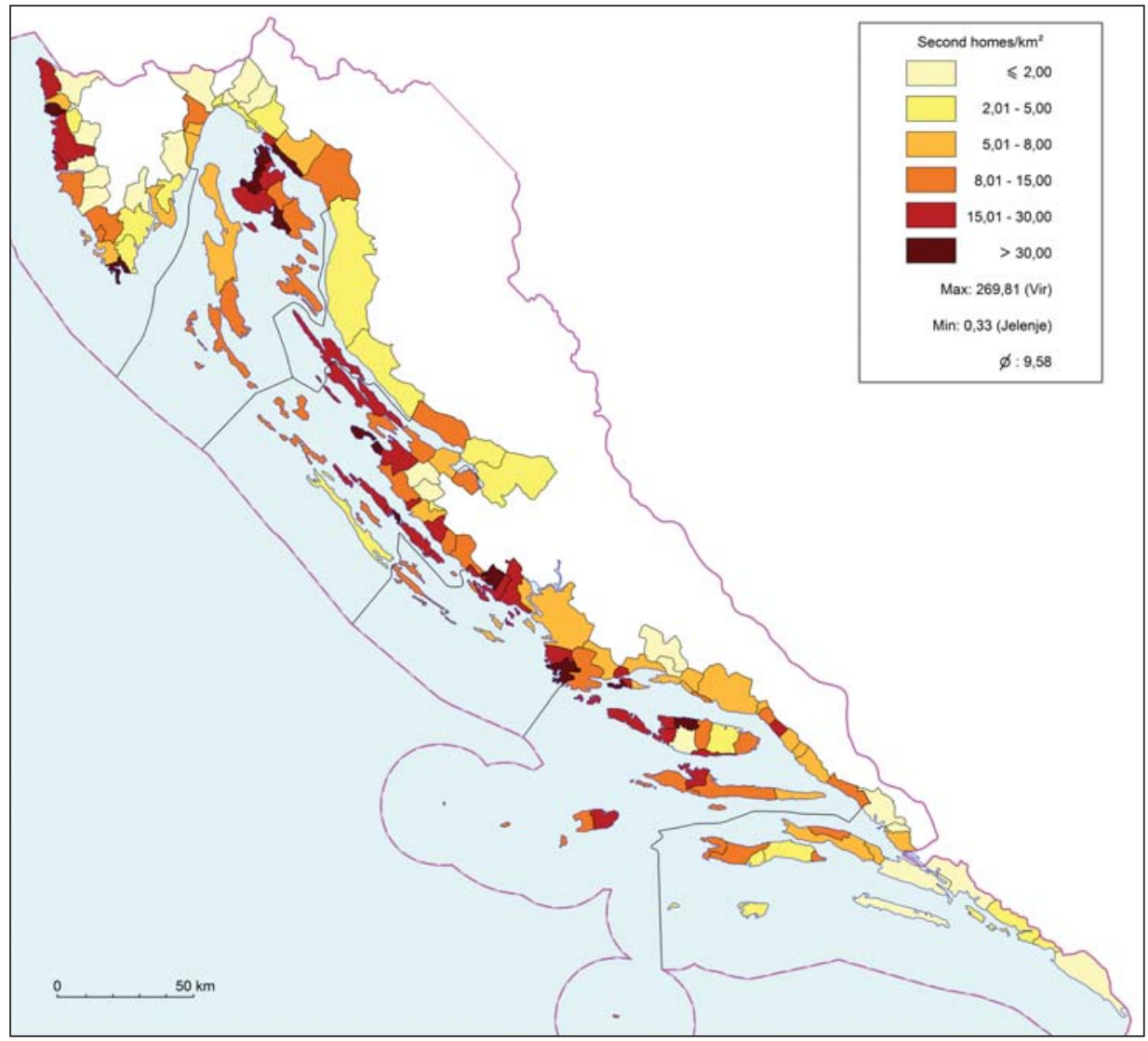

Fig. 5 The density of the dwellings for vacation and recreation in towns and municipalities of the Croatian littoral in 2001

Sl. 5. Gustoća stanova za odmor i rekreaciju u gradovima i općinama priobalnoga dijela Hrvatske 2001. godine

Source: Census of Population, Households and Dwellings $31^{\text {st }}$ March 2001, Dwellings according to the manner of use by towns/municipalities, Second edition, Central Bureau of Statistics of the Republic of Croatia, Zagreb, 2003.

http://www.dzs.hr/Popis\%202001/popis20001.htm 
The indices of the density of dwellings for vacation and recreation in units of local self-government of the Croatian littoral in 2001 ranged from 269.81 dwellings for vacation and recreation $/ \mathrm{km}^{2}$ (Vir) and 0.33 second dwellings $/ \mathrm{km}^{2}$ (Jelenje). The towns/municipalities with highest indices of the density of dwellings for vacation and recreation per area unit include in similar proportions units of local self-government from the Northern and the Southern Croatian Littoral. Density over 30 second homes $/ \mathrm{km}^{2}$ is registered in 13 towns/municipalities of the Croatian littoral. They are: Vir (269.81), Crikvenica (140.99), Okrug (140.80), Privlaka (94.63), Malinska-Dubašnica (57.91), Pirovac (45.48), Omišalj (41.06), Medulin (38.48), Kukljica (34.15), Novigrad (in Istria) (33.42), Supetar (33.37), Rogoznica (33.22) and Punat (32.37). Although the index of density in second dwellings is predominantly influenced by the size of the area belonging to a given unit of local selfgovernment, the order of towns/municipalities with highest concentration of second homes in the Croatian littoral clearly indicates that its "most significant strongholds" are located in the receiving second home areas of the Kvarner, West Istria and North Dalmatia.

As in previous censuses, the lowest indices of the density of dwellings for vacation and recreation in the Croatian littoral are found in units of local self-government, often in the hinterland areas, which shows evidence of rather underdeveloped occasional recreational dwelling (e.g. Poličnik - 0.62 dwellings for vacation and recreation $/ \mathrm{km}^{2}$, Matulji - 0.56, Zemunik Donji - 0.49, Ploče - 0.43, Barban -0.34, Jelenje - 0.33) or in towns/municipalities with largest area which, despite noticeable number of dwellings for vacation and recreation, still register a relatively low index of their density (e.g. Senj$3.86 \mathrm{dwellings}$ for rest and recreation $/ \mathrm{km}^{2}$, Obrovac - 3.54, Dubrovnik - 3.00, Klis - 1.98, Ston -1.90 , Konavle -0.58 , Dubrovačko primorje - 0.56).

\section{THE RATIO BETWEEN THE NUMBER OF DWELLINGS FOR VACATION AND RECREATION AND PERMANENTLY OCCUPIED DWELLINGS IN THE CROATIAN LITTORAL IN 2001}

The average index of dwellings for vacation and recreation and permanently occupied dwellings in the towns/municipalities of the coastal and insular part of Croatia in 2001 was 28.84 second homes per 100 permanently occupied dwellings, which is just a little more than in 1991 (27.01 dwellings for vacation and recreation per 100 permanently occupied dwellings) (Fig. 6).

The indices for the ratio between dwellings for vacation and recreation and permanently occupied dwellings in the towns/municipalities of the Croatian littoral in 2001 ranged from 1159.53 dwellings for vacation and recreation per 100 permanently occupied dwellings (Vir) and 0.20 second homes per 100 permanently occupied dwellings (Rijeka). Because of the prevalence of the function of work and permanent stay in larger cities and towns, this index may incorrectly suggest the presence - and consequently the transforming power - of the second home phenomenon, since the dwellings for vacation and recreation tend to "get lost" in the high number of permanently occupied dwellings (e.g. Dubrovnik -3.03 dwellings for vacation and recreation per 100 permanently occupied dwellings, Pula-1.62, Split -0.91 , Rijeka -0.20 ). For the reasons mentioned the ratio between these two elements of the housing stock did not reflect particular spatial regularity. 


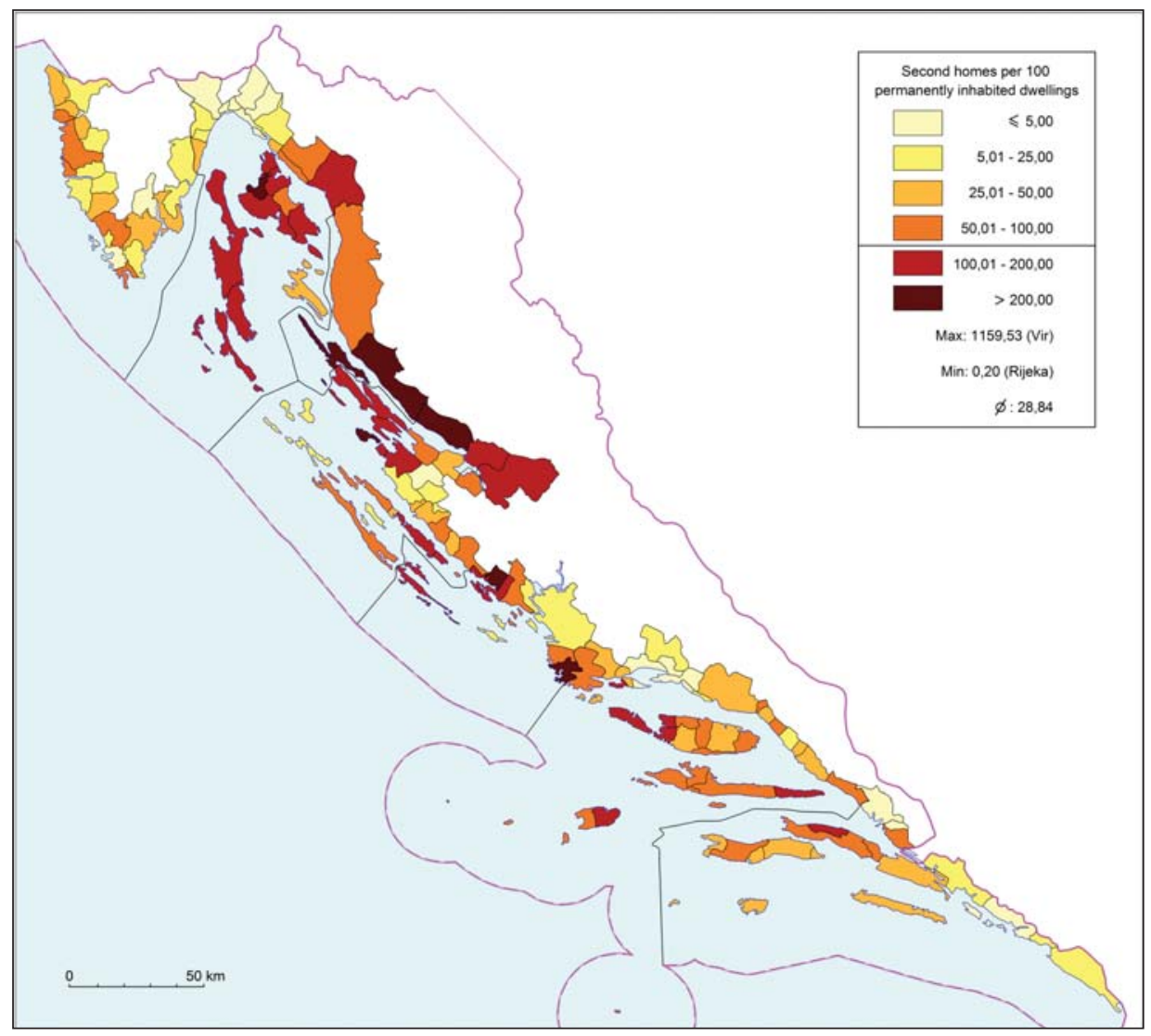

Fig. 6 The ratio between dwellings for vacation and recreation and permanently occupied dwellings in towns and municipalities of the Croatian littoral in 2001

Sl. 6. Odnos broja stanova za odmor i rekreaciju i stalno nastanjenih stanova u gradovima $i$ općinama priobalnoga dijela Hrvatske 2001. godine

Source: Census of Population, Households and Dwellings $31^{\text {st }}$ March 2001, Dwellings according to the manner of use by towns/municipalities, Second edition, Central Bureau of Statistics of the Republic of Croatia, Zagreb, 2003.

http://www.dzs.hr/Popis\%202001/popis20001.htm

According to the statistics for 2001, one of the indications of the stagnation of the second home phenomenon in the Croatian littoral is also the fact that 33 out of the total of 134 units of local self-government register more second homes than permanently occupied dwellings, while in 1991 the same ratio was registered in 32 units of local self-government, that is, in only one unit of local self-government fewer. Since in the last inter-census period (1991 - 2001) the number of inhabitants of the Croatian littoral did not increase (but actually decreased by 40511 inhabitants), the stagnating ratio between dwellings for vacation and recreation and permanently occupied dwellings may be ascribed to the lack of growth, i.e. the insignificant increase, in the number of second homes. One certainly has to take into account that, same as in other segments of the analysis of statistical information, we 
deal with official information from the census which, as has already been observed, are for various reasons at odds with the real situation "on the ground".

While in 1991 in 11 units of local self-government dwellings for vacation and recreation outnumbered permanently occupied dwellings by one hundred percent, in 2001 the same ratio was registered in only 7 towns/municipalities of the Croatian littoral, primarily in the area of North Dalmatia and the Velebit coast. The seven towns/municipalities with twice as many second homes than permanently occupied dwellings in 2001 were: Vir (1159.53 dwellings for rest and recreation per 100 permanently occupied dwellings, or more than 11 and a half times more second homes than permanently occupied dwellings), Pirovac (291.22), Karlobag (265.03), Rogoznica (247.70), Malinska-Dubašnica (229.68), Starigrad (209.92) and Novalja (203.95).

The lower values of the ratio between dwellings for vacation and recreation and the permanently occupied dwellings, with the exception of units of local self-government in larger urban centres (in the already mentioned Dubrovnik, Pula, Split, Rijeka), were registered in 2001 also in the towns/municipalities of the Croatian littoral in which the second home phenomenon manifested a lower degree of development (e.g. Matulji -2.74 dwellings for vacation and recreation per 100 permanently occupied dwellings, Čavle - 2.68, Jelenje - 2.18, Kostrena - 2.15, Kastav - 0.88, Viškovo - 0.57).

\section{CONCLUSION}

Ever since the systematic statistical information about the second home phenomenon in Croatia started to be collected, Croatian littoral has been and remained the main receiving second home area (hot spot). Mountainous regions (Gorski kotar, and of lately, Lika) and hilly regions in the vicinity of larger towns of the hinterland (e.g. Hrvatsko zagorje, rural recreational environs of Zagreb) and the areas adjacent to hydrographical resources (rivers, lakes; Lika and Kordun region adjacent to the Plitvice Lakes National Park) are secondary receiving areas in the country, while the flat land (e.g. Slavonia) is significantly less attractive area with regard to the second home phenomenon.

Despite stagnation indicated by official information, as a result of the building of multi-apartment recreational buildings which was more intensive in the inter-census period from 1991 to 2001 than in the previous periods, the second home phenomenon revealed an increased level of concentration in its initial core region - the Croatian littoral.

Due to the vicinity and good communications with the most significant emissive second home areas (Zagreb with other cities of Central Croatia, Rijeka, Slovenia), the second home phenomenon in the Croatian littoral first spread across the Kvarner and Istria, and then in 1980 to 1990 registered significant growth also in Dalmatia. The different level of exposure to military operations, devastation and the post-war difficulties created differentiated development of the secondary dwelling in the Northern and Southern Croatian Littoral. For this reason the development of the second home phenomenon, which started several decades earlier, continued, although at a slower pace, in the Kvarner and 
Istria, areas of the Croatian littoral which had been spared direct war devastation, while the Dalmatian littoral for the most part witnessed a halt in the development of secondary recreational dwelling.

The spatial distribution of dwellings for vacation and recreation for 2001 reveals that the intervening period $(1991-2001)$ saw the continuation of the earlier trend for the concentration of secondary dwelling in the leading tourist areas, but also an even more manifest dispersion in the areas considered to be of lesser tourist significance and not as likely to attract and support significant second home growth. It must be pointed out that in this period, due to real estate price increases (now realistic, achieving market value) and higher demand for real estate, more and more multi-apartment buildings for vacation and recreation are being built in the most attractive second home areas, while the bulk of individual building "moves" to the areas in the immediate hinterland.

The leading receiving second home areas in the Croatian littoral are: the CrikvenicaVinodol coast, the islands of the Kvarner (primarily the island of Krk), the West coast of Istria, the Velebit coast with the island of Pag, the coast of the Novigrad and Karin sea, the Zadar and Šibenik coast with the islands of Vir and Murter. The secondary receiving second home areas of the Croatian littoral, areas situated farther away from the leading domestic emissive second home area of Central Croatia, are the region of the Split urban region including also the pen(insula) of Čiovo, Middle Dalmatian islands and the peninsula of Pelješac, and the island of Korčula.

In 2001 the Croatian islands registered more dwellings for vacation and recreation that permanently occupied dwellings, which points to the ongoing growth of the tourismrecreational function and the decrease in the employment-accommodation function (accelerated process of depopulation on most Croatian islands). All this supports the fact that the Croatian insular space transforms through the emergence and rapid growth of tourism and the second home phenomenon from a production area into a consumption area, which characterises numerous receiving second home areas in Europe and the world. In 2001 the islands of North Dalmatia (predominantly Vir, Pag and Murter which are connected with the mainland by a bridge) registered more second homes than on other large groups of islands of the Croatian littoral. Next in terms of the number of dwellings for vacation and recreation came the Kvarner group of islands (primarily Krk - with the mainland connected by the bridge, Lošinj, Cres and Rab), then the islands of Middle Dalmatia (primarily Brač, Hvar, Čiovo - bridge connection, Vis and Šolta), while the bottom of the list of groups of islands in terms of secondary recreational dwellings is occupied by the islands of South Dalmatia out of which only Korčula registered a slightly higher concentration of secondary recreational dwellings. The islands with the highest number of second homes, classified according to the location of islands in regard to the mainland, were coastal islands, closest to the mainland, followed by channel islands and the open sea islands, farthest away from the mainland. The decisive factor for the development of the second home phenomenon on islands was the distance, i.e. the frequency and regularity of ferry/ship/catamaran communications between the island and the mainland.

The main "wave" of the second home development in the Croatian littoral after the Homeland War started in the early 2000s after the complete stabilisation of the difficult 
circumstances of the early 1990s. In this period Croatia underwent tourism revival which also reflected on the increased domestic as well as foreign demand for second homes.

The census of 2001 understandably could not register the most recent second home "boom", primarily characterised by multi-apartment recreational buildings. For this reason the next census, expected in 2011, will indubitably give a more realistic picture of the second home phenomenon in the Croatian littoral.

\section{NOTES}

1. The purpose of the inclusion in the study of 12 towns and municipalities which are not located on the coast but are within $10 \mathrm{~km}$ of road distance from the nearest coastal settlement (the towns/municipalities in question are: Kaštelir-Labinci and Višnjan from the Istria county, Čavle, Jelenje, Kastav, the Municipality of Vinodol and Viškovo in Primorje-Gorski kotar county, Galovac, Poličnik and Zemunik Donji in the Zadar county, Klis in the Split-Dalmatia county and Opuzen in the Dubrovnik-Neretva county) was to adjust the administrative-territorial structure to geographical reality. In some cases the administrative territories of certain "coastal towns/municipalities" extend far into the hinterland (e.g. the Town of Omiš which includes numerous settlements of the Dalmatian hinterland (Dalmatinska zagora) which due to the relief barrier do not belong to the Croatian littoral). On the other hand there exist units of local self-government which cannot justifiably be excluded from the geographical framework of this study even though they do not have access to the coast but belong to it because of its proximity, functional connections, physical-geographic features, the lifestyle of local population and, finally, because of the characteristics of the second home phenomenon which they display (e.g. the Municipality Vinodolska općina with its administrative HQ in Bribir, which is functionally inseparable from Crikvenica and located in its immediate hinterland even though it does not have actual access to the coast).

2. The number of units of local self-government applies to the actual situation in the critical time of the Census of 2001 ( $31^{\text {st }}$ March 2001). Even though between the last census and today there have been some changes related to the administrative-territorial structure on the level of town/municipality, they have been deliberately ignored in this study which takes numerical and cartographical information as valid on $31^{\text {st }}$ March 2001 .

3. The insular region of Croatia is divided into several groups of islands. Following the established division to large groups of islands, Croatian islands with registered second home phenomenon are classified as: Kvarner islands (Cres, Ilovik, Krk, Lošinj, Male Srakane, Rab, Susak, Unije, Vele Srakane), North Dalmatian islands (Dugi otok, Ist, Iž, Kaprije, Kornat, Krapanj, Molat, Murter, Olib, Ošljak, Pag, Pašman, Premuda, Prvić, Rava, Rivanj, Sestrunj, Silba, Ugljan, Vir, Vrgada, Zlarin, Zverinac, Žirje), Middle Dalmatian islands (Biševo, Brač, Čiovo, Drvenik Mali, Drvenik Veli, Hvar, Sveti Andrija, Šolta, Vis) and South Dalmatian islands (Koločep, Korčula, Lastovo, Lopud, Mljet, Šipan). Croatian islands are also grouped according to the location in relation to the mainland and divided into the following three groups: coastal (Brač, Čiovo, Drvenik Mali, Drvenik Veli, Koločep, Krapanj, Krk, Lopud, Murter, Ošljak, Pag, Pašman, Prvić, Rab, Šipan, Šolta, Ugljan, Vir, Vrgada, Zlarin), channel (Cres, Hvar, Ist, Iž, Kaprije, Korčula, Lošinj, Mljet, Molat, Olib, Rava, Rivanj, Sestrunj, Zverinac) and open sea (Biševo, Dugi otok, Ilovik, Kornat, Lastovo, Male Srakane, Premuda, Silba, Susak, Sveti Andrija, Unije, Vele Srakane, Vis, Žirje) (Lajić, Mišetić, 2006).

4. The totality of the insular area includes all Croatian islands with registered information related to secondary dwelling. The coastal part consists of the rest of the Croatian littoral, i.e. towns and municipalities with access to sea as well as the above mentioned 12 municipalities and towns which are classified as an integral part of the Croatian littoral for the purposes of this study because of their functional connectedness and inseparability from the coastal area (see note 1). The continental part of Croatia includes all counties without access to sea, as well as those parts of continental counties with access to sea which are outside the scope of the Croatian littoral as defined earlier. 
5 In the circumstances of the increased economic and demographic littoralisation (Faričić, 2006) which largely defined the period of the growth of coastal urban centres as well as the "chaotic" development of tourism, coastal agriculture was largely ignored so that a large number of smaller coastal settlements, and particularly in the islands' hinterland, experienced intensive depopulation (Vlahović, 1989; Nejašmić, 1991; Nejašmić, 1999), which increased the offer of old, vacated houses and abandoned economic object, and brought down their prices, which were already rather low for the richer urban population. In addition to depopulation caused by emigration, common outside larger urban centres of the coastal and even more insular Croatian space in the circumstances of industrially oriented littoralisation, the vacation of the housing fund in parts of the Croatian littoral which were under Italian administration during the Second World War (e.g. the coastal towns of Istria, predominantly Rovinj (Bertić, 1977; Bertić, 1979), Poreč, Novigrad, Vrsar, but also Rijeka i Zadar etc.) was affected by the emigration of a segment of Italian population (optanti or esuli). In order to protect the abandoned dwellings from destruction they were populated by the new permanent but also temporary occupants - second home owners (Jeršič, 1968; Blažević, 1987).

6 Typical examples of early purpose-built recreational apartment villages from late 1980s in the Croatian littoral are Červar-Porat near Poreč, Barbariga on the West coast of Istria between Rovinj and Pula, Mareda near Novigrad in Istria and Gajac near Novalja on the island of Pag.

7 From February $1^{\text {st }}$, 2009, on the basis of the Stabilisation and Association Agreement between Croatia and European Union, foreign natural and legal persons of EU member states may become owners of real estates under the same conditions as Croatian citizens. Exceptions to these regulations are only agricultural land, forests and estates located in the protected areas.

8 After the collapse of Yugoslavia, independent Croatia, in an attempt to alleviate negative effect of development caused by the general concentration of developmental potentials in about a hundred administrative centres (municipal monocentrism), abandoned the earlier system of municipal administrative-territorial structure and adopted division into counties. Below the regional level of division into counties, Croatia is divided into 556 units of local self-government - 127 towns and 429 municipalities. Even though it was recognised that this organisation sought to sustain a more evenly distributed regional and local development, practice has revealed that a large number of units of local self-government is economically and demographically unsustainable.

9 Even though private property was not forbidden in Croatia during the socialist period, the system did not guarantee the owner's authority. The state had great manoeuvring abilities for manipulating private property which allowed the state to impose dispossession, in those cases which it declared to be of "higher" state interest, relatively quickly and elegantly (Rogić, 2006).

10 The index of change in the number of dwellings for vacation and recreation from 1991 to 2001 was calculated simply: the number of dwellings for vacation and recreation in 2001 was divided by the number of dwellings for vacation and recreation in 1991 and multiplied by 100 .

11 In the period from 1991 to 2001 the Kvarner islands registered the increase in the number of dwellings for vacation and recreation by $32.88 \%$, the islands of the North Dalmatia $23.55 \%$, the islands of South Dalmatia $23.40 \%$, while the number of second dwellings stagnated only on Middle Dalmatian islands with the increase of only $3.25 \%$ ).

\section{REFERENCES}

Alfier D., 1987: Uzroci i posljedice pretjerane izgradnje kuća za odmor i rekreaciju na području Jugoslavije, Turizam 35(6), 165-171

Bertić I., 1977: Rovinj - razvoj turizma i transformacija naselja pod njegovim utjecajem, Geografski glasnik $39,89-120$

Bertić I., 1979: Rovinjština: geografske značajke primorske mikroregije i njezinog gradskog središta, Geografski horizont 25(1-2), 13-39 
Vuk Tvrtko Opačić - Recent Characteristics of the Second Home Phenomenon in the Croatian Littoral

Blažević I., 1984: Turizam Istre, Savez geografskih društava Hrvatske, Zagreb

Blažević I., 1987: Dinamika izgradnje i prostorni razmještaj stanova za odmor i rekreaciju na području Istre i Kvarnera, Zbornik radova 15. znanstvenog skupa „Susreti na dragom kamenu”, 327-335

Chaplin D., 1999: Consuming work/productive leisure: the consumption patterns of second home environments, Leisure Studies 18(1), 41-55

Duda I., 2005: U potrazi za blagostanjem: o povijesti dokolice i potrošačkog društva u Hrvatskoj 1950-ih i 1960-ih, Srednja Europa, Zagreb

Faričić J., 2006: Sjevernodalmatinski otoci u procesu litoralizacije - razvoj, problemi i perspektive, doktorska disertacija, Geografski odsjek Prirodoslovno-matematičkog fakulteta Sveučilišta u Zagrebu, Zagreb

Gallent N., Tewdwr-Jones M., 2000: Rural second dwellings in Europe: examining housing supply and planning control, Ashgate, Aldershot, Burlington

Gosar A., 1989: Second dwellings in the Alpine region of Yugoslavia, Mountain Research and Development $9(2), 165-174$

Gustafson P., 2002: Tourism and seasonal retirement migration, Annals of Tourism Research 29(4), 899-918

Halseth G., 2004: The „,cottage” privilege: increasingly elite landscapes of second dwellings in Canada, in Hall C. M., Müller D. K. (ed.) Tourism, mobility and second dwellings: between elite landscape and common ground, Channel View Publications, Clevedon, Buffalo, Toronto, 35-54

Jeršič M., 1968: Sekundarna počitniška bivališča v Sloveniji in Zahodni Istri, Geografski vestnik 40, 53-67

Klarić Z., 1989: Sekundarne rezidencije u Jugoslaviji - prostorni raspored i utjecaj na okolinu, Geografski glasnik 51, 75-90

Lajić I., Mišetić R., 2006: Otočni logaritam: aktualno stanje i suvremeni demografski procesi na jadranskim otocima, Institut za migracija i narodnosti, Ministarstvo mora, turizma, prometa i razvitka, Zagreb

Mikačić V., 1994: Otočni turizam Hrvatske, Društvena istraživanja 3(4-5), 517-529

Mikačić V., 2007: Utjecaj rezidencijalnog turizma na primorski prostor Hrvatske, in Filipčić A. (ed.) Zbornik radova Četvrtog hrvatskog geografskog kongresa, Hrvatsko geografsko društvo, Zagreb, 321-336

Müller D. K., 1999: German second home owners in the Swedish countryside: on the internationalization of the leisure space, European Tourism Research Institute, Department of Social and Cultural Geography, Östersund, Umeå

Müller D. K., 2002: German second home owners in Sweden: some remarks on the tourism - migration - nexus, Revue Européene des Migrations Internationales 18(1), 67-86

Müller D. K., 2004: Mobility, tourism and second dwellings, in Lew A. A., Hall C. M., Williams A. M. (ed.) A companion to tourism, Blackwell Publishing, Malden, Oxford, Calden, 387-398

Müller D. K., Hall C. M., 2004: The future of second home tourism, in Hall C. M., Müller D. K. (ed.) Tourism, mobility and second dwellings: between elite landscape and common ground, Channel View Publications, Clevedon, Buffalo, Toronto, 273-278

Nejašmić I., 1991: Depopulacija u Hrvatskoj: korijeni, stanje, izgledi, Globus i Institut za migracije i narodnosti, Zagreb

Nejašmić I., 1999: Uloga turizma u diferenciranom demografskom razvitku otočnih naselja: primjer srednjodalmatinskog otočja, Hrvatski geografski glasnik 61, 37-52

Opačić V. T., 2008: Ekonomsko-geografski utjecaji i posljedice vikendaštva u receptivnim vikendaškim područjima - primjer otoka Krka, Ekonomska misao i praksa 17(2), 127-154

Pepeonik Z., 1977: Stanovi za odmor i rekreaciju u Jugoslaviji, Geographica Slovenica 5, 181-194

Pepeonik Z., 1983: Prostorni raspored i osnovne značajke stambenih objekata za odmor i rekreaciju u SR Hrvatskoj, Geografski glasnik 45, 91-103 
Poljanec-Borić S., 1991: Simbolika vikendice, in Marković, S., Dragičević, M. (ed.) Zbornik radova, Institut za turizam, Zagreb, 211-224

Rodríguez V., 2001: Tourism as a recruiting post for retirement migration, Tourism Geographies 3(1), 52-63

Rogić I., 2006: Odnos spram kuće za odmor u Hrvatskoj u strategiji urbanizacije 1945.-2005., Društvena istraživanja 15(1-2), 3-26

Truly D., 2002: International retirement migration and tourism along the Lake Chapala Riviera: developing a matrix of retirement migration behaviour, Tourism Geographies 4(3), 261-281

Vlahović D., 1989: Specifični problemi razvoja turizma dalmatinskih otoka, Turizam, 37(5), 132-143

Warnes A. M., Patterson G., 1998: British retirees in Malta: components of the cross-national relationship, International Journal of Population Geography 4, 113-133

Williams A. M., King R., Warnes T., 1997: A place in the sun: international retirement migration from northern to southern Europe, European Urban and Regional Studies 4(2), 115-134

Williams A. M., King R., Warnes T., 2004: British second dwellings in Southern Europe: shifting nodes in the scapes and flows of migration and tourism, in Hall C. M., Müller D. K. (ed.) Tourism, mobility and second dwellings: between elite landscape and common ground, Channel View Publications, Clevedon, Buffalo, Toronto, 97-112

\section{SOURCES}

Census of Population and Dwellings 1971, Dwellings for vacation and recreation. Statistics by settlements and municipalities, Book 6, Federal Bureau of Statistics, Beograd, 1973.

Census of Population, Households and Dwellings 31 ${ }^{\text {st }}$ March 1981, Households and dwellings. Statistics for settlements by municipalities, Dwellings and area by usage and other inhabited rooms and persons, Republic Bureau of Statistics, Zagreb, 1982.

Census of Population, Households, Dwellings and Farms 31 ${ }^{\text {st }}$ March 1991, Dwellings for vacation and recreation by settlements, Documentation 929, Central Bureau of Statistics of the Republic of Croatia, Zagreb, 1996.

Census of Population, Households and Dwellings 31 $3{ }^{\text {st }}$ March 2001, Dwellings according to the manner of use by towns/municipalities, Second edition, Central Bureau of Statistics of the Republic of Croatia, Zagreb, 2003.

http://www.dzs.hr/Popis\%202001/popis20001.htm

Census of Population, Households and Dwellings $31^{\text {st }}$ March 2001, Dwellings according to the manner of use by settlements, Internal information, Central Bureau of Statistics of the Republic of Croatia, Zagreb, 2003.

Census of Population, Households and Dwellings 31 ${ }^{\text {st }}$ March 2001, Population by presence/absence by settlements, Second edition, Central Bureau of Statistics of the Republic of Croatia, Zagreb, 2003. http://www.dzs.hr/Popis\%202001/popis20001.htm 


\title{
SAŽETAK
}

\section{Suvremena obilježja vikendaštva u hrvatskom priobalju}

\author{
Vuk Tvrtko Opačić
}

Kao i u ostalim dijelovima svijeta s razvijenim vikendaštvom, u Hrvatskoj je broj objekata za odmor i rekreaciju najnaglašeniju ekspanziju zabilježio u posljednjih četrdesetak godina. Zbog iznimnih rekreacijskih, ali i iznajmljivačkih pogodnosti, glavnina vikendica u Hrvatskoj tradicionalno je koncentrirana u njezinu obalnome i otočnom području, ujedno i turistički najrazvijenijem dijelu, pa se priobalje opravdano može smatrati vodećim receptivnim vikendaškim područjem u državi (tzv. hot spot). Planinska područja (Gorski kotar, u posljednje vrijeme i Lika), brežuljkasta područja u blizini većih gradova u unutrašnjosti (npr. Hrvatsko zagorje; ruralna rekreacijska okolica Zagreba) te područja uz hidrografske resurse (rijeke, jezera; npr. prijelazni prostor Like i Korduna u blizini nacionalnoga parka Plitvička jezera) sekundarno su receptivno vikendaško područje u državi, dok je nizinski prostor (npr. Slavonija) s vikendaškog aspekta znatno slabije valorizirano područje.

Pojava i razvoj vikendaštva na razne su načine snažno utjecali na direktnu i indirektnu preobrazbu priobalnoga prostora Hrvatske. Kako bi se moglo započeti s detaljnim istraživanjima uloge sekundarnoga (rekreacijskog) stanovanja u lokalnim zajednicama receptivnih vikendaških područja hrvatskoga priobalja te potom donijeti adekvatne prostorno-planske smjernice njegova daljnjeg usmjeravanja, najprije je potrebno istražiti karakteristike razvojne dinamike i prostornog rasporeda te kompleksne pojave u ,regiji jezgre" vikendaštva u Hrvatskoj te izdvojiti njezina „vikendaška žarišta”. Potonje se nameće i kao glavni cilj ovoga istraživanja.

Rad se temelji na analizi teorijske i empirijske domaće i strane znanstvene i stručne literature iz geografije i ostalih srodnih znanosti, kao i interpretaciji popisne statistike. Naime hrvatski popisi stanovništva, kućanstava i stanova od popisa 1971. obuhvaćaju i stanove za odmor i rekreaciju, i to kao zasebnu kategoriju unutar stambenoga fonda.

U međupopisnom razdoblju 1991.-2001. vikendaštvo u Hrvatskoj, usprkos stagnantnim razvojnim tendencijama (prema službenim podacima), zbog intenzivnije višestambene apartmanske izgradnje u usporedbi s prijašnjim razmotrenim razdobljima pokazalo je nešto izraženiju tendenciju koncentracije u prostoru svoje inicijalne jezgre - hrvatskom priobalju.

Vikendaštvo u priobalnom dijelu Hrvatske najprije je, zbog blizine i prometne dostupnosti najvažnijih emitivnih vikendaških područja (Zagreb s ostalim gradovima Središnje Hrvatske, Rijeka, Slovenija), zahvatilo Kvarner i Istru, a potom od 1980. do 1990. znatno ojačalo i u Dalmaciji. Različita izloženost ratnim i poratnim okolnostima utjecala je na diferenciran razvoj sekundarnog stanovanja u Sjevernom i Južnom hrvatskom primorju. Tako se na Kvarneru i u Istri, dijelovima hrvatskoga priobalja pošteđenim izravnih ratnih razaranja, proces jačanja vikendaštva iz prethodnih desetljeća nastavio, premda sporije, dok je u najvećem dijelu priobalnoga prostora Dalmacije došlo do zastoja u razvojnim tendencijama sekundarnoga rekreacijskog stanovanja.

Prostorni raspored stanova za odmor i rekreaciju 2001. otkriva da su se i u posljednjemu međupopisnom razdoblju (1991.-2001.) zadržale prijašnje tendencije koncentracije sekundarnoga stanovanja u vodećim obalnim turističkim područjima, ali i sve izraženija disperzija u turistički manje vrednovana područja pogodna za vikendašku valorizaciju. Pritom valja istaknuti da se zbog sve veće (sada realne, tržišne) cijene nekretnina, ali i sve izraženije potražnje, u najpoželjnijim vikendaškim 
područjima sve češće grade višestambeni apartmanski objekti, dok se glavnina individualne izgradnje vikendica ,pomiče” u pozadinske zone u bližem zaleđu.

Kao vodeća receptivna vikendaška područja u hrvatskom priobalju mogu se izdvojiti: Crikveničko-vinodolsko primorje, Kvarnerski otoci (ponajviše otok Krk), zapadna obala Istre, Podvelebitsko primorje s otokom Pagom, primorje Novigradskoga i Karinskoga mora te Zadarsko i Šibensko primorje s otocima Virom i Murterom, dok se, od Središnje Hrvatske vodećega domaćeg emitivnog vikendaškog područja nešto udaljeniji obalni prostor splitske aglomeracije, uključujući i (polu)otok Čiovo, Srednjodalmatinski otoci te poluotok Pelješac i otok Korčula ističu kao sekundarna receptivna vikendaška područja priobalnoga dijela Hrvatske.

Na hrvatskim je otocima 2001. popisano više stanova za odmor i rekreaciju nego stalno nastanjenih stanova, što upućuje na nastavak prije započetih procesa jačanja turističko-rekreacijske funkcije, uz istodobno smanjivanje radno-stambene funkcije (uznapredovali depopulacijski procesi na većini hrvatskih otoka). Navedeno potvrđuje činjenicu da se otočni prostor Hrvatske-pojavom i jačim razvojem turizma i vikendaštva - iz prostora proizvodnje sve više pretvara u prostor potrošnje, što obilježava brojna receptivna vikendaška područja u Europi i svijetu. Na otocima Sjeverne Dalmacije (najviše na mostovima povezanima Viru, Pagu i Murteru) popisano je 2001. više vikendica nego na ostalim velikim otočnim skupinama hrvatskoga priobalja. Brojnošću stanova za odmor i rekreaciju slijedila je Kvarnerska otočna skupina (najviše Krk, Lošinj, Cres i Rab), zatim Srednjodalmatinska otočna skupina (najviše Brač, Hvar, mostom spojeno Čiovo, Vis te Šolta), dok se, između nabrojenih četiriju otočnih skupina, prema broju stambenih jedinica sekundarnoga rekreacijskog stanovanja na začelju nalaze Južnodalmatinski otoci, od kojih je jedino na Korčuli registrirana nešto veća koncentracija sekundarnih rekreacijskih stanova. S obzirom na položaj otoka u odnosu na kopno, brojem vikendica prednjačili su, kopnu najbliži, priobalni otoci, ispred udaljenijih kanalskih te najudaljenijih pučinskih otoka. Za razvoj vikendaštva na otocima presudnim se čimbenikom pokazala udaljenost, odnosno trajektna/brodska povezanost otoka s kopnom.

Glavni val jačanja vikendaštva nakon Domovinskog rata u hrvatskom priobalju nastupio je početkom 21. stoljeća, nakon potpune stabilizacije nepovoljnih prilika iz prve polovine devedesetih godina 20. stoljeća, kada Hrvatska doživljava turistički preporod, što se odrazilo i na pojačanu domaću, ali i stranu vikendašku potražnju. Spomenuti najnoviji vikendaški, poglavito apartmanski boom, kojemu svjedočimo već pri prvom susretu s istraživanim prostorom, popis iz 2001., naravno, nije mogao registrirati, pa će realniju sliku vikendaške prisutnosti u priobalnom dijelu Hrvatske nesumnjivo dati sljedeći popis stanovništva, kućanstava i stanova, koji se očekuje 2011. godine.

Vuk Tvrtko Opačić, $\mathrm{PhD}$, assistant professor, Department of Geography, Faculty of Science, University of Zagreb, Marulićev trg 19/II, 10000 Zagreb, Croatia e-mail: vtopacic@geog.pmf.hr 